\title{
Excavations at the Alamo Shrine (Mission San Antonio de Valero)
}

\author{
Jack D. Eaton
}

Center for Archaeological Research

Follow this and additional works at: https://scholarworks.sfasu.edu/ita

Part of the American Material Culture Commons, Archaeological Anthropology Commons, Environmental Studies Commons, Other American Studies Commons, Other Arts and Humanities Commons, Other History of Art, Architecture, and Archaeology Commons, and the United States History Commons

Tell us how this article helped you.

This Article is brought to you for free and open access by the Center for Regional Heritage Research at SFA ScholarWorks. It has been accepted for inclusion in Index of Texas Archaeology: Open Access Gray Literature from the Lone Star State by an authorized editor of SFA ScholarWorks. For more information, please contact cdsscholarworks@sfasu.edu. 


\section{Excavations at the Alamo Shrine (Mission San Antonio de Valero) \\ Creative Commons License \\ (c) $($ ) $(9)$}

This work is licensed under a Creative Commons Attribution-NonCommercial 4.0 International License 


\section{EXCAVATIONS AT THE aLAMO SHRINE}

(MISSION SAN ANTONIO DE VALERO)

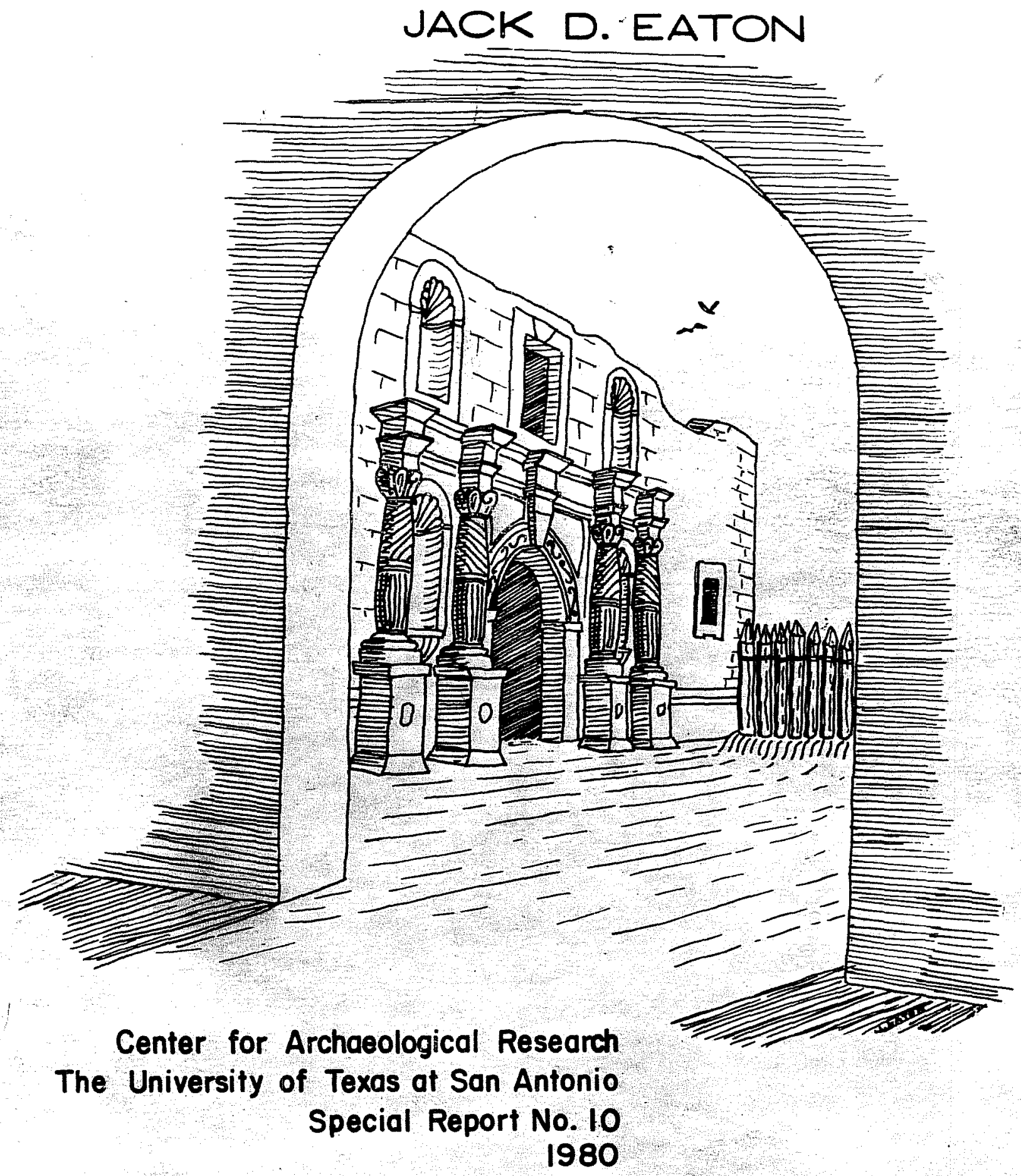


EXCAVATIONS AT THE ALAMO SHRINE

(Mission San Antonio de Valero)

\author{
Jack D. Eaton
}

Center for Archaeological Research

The University of Texas at San Antonio

Special Report, No. 10

1980 
The following information is provided in accordance with General Rule of Practice and Procedure, 355.01.011C, Texas Antiquities Committee:

1. Archaeological testing in front of Alamo Shrine;

2. Excavations at the Alamo Shrine (San Antonio de Valero);

3. Bexar County, Texas;

4. Thomas R. Hester, Principal Investigator; Jack D. Eaton, Field Director and Author;

5. City of San Antonio;

6. Texas Historical Commission Antiquities Permit No. 139;

7. Published by the Center for Archaeological Research, The University of Texas at San Antonio, San Antonio, Texas 78285; December 1980. 
List of figures................... . . ii

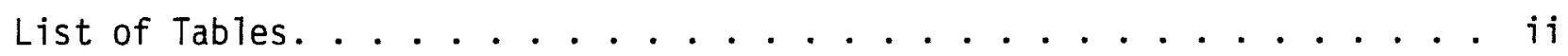

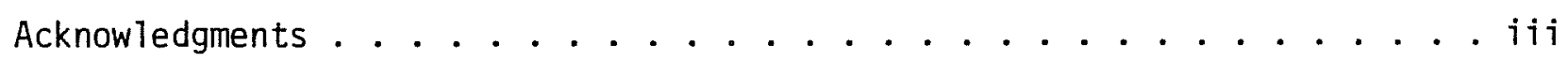

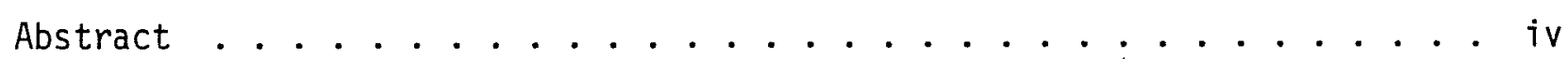

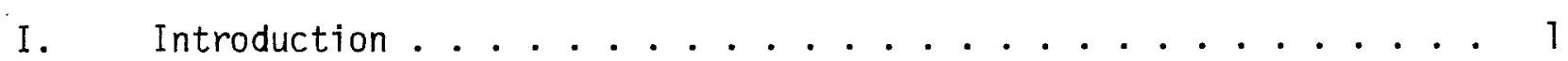

II. Historical Background ................. 3

III. The Architecture ................. 13

IV. Previous Archaeological Investigations . . . . . . . . . . 17

V. The Alamo Shrine Excavations ............... 21

VI. The Artifacts ................... . . 27

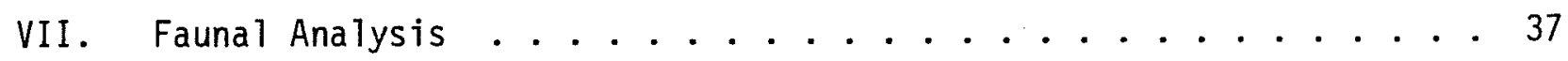

VIII. Concluding Remarks ................. 45

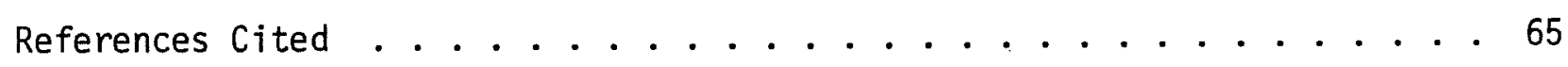




\section{LIST OF FIGURES}

Figure

Page

1. Mission San Antonio de Valero .............. 49

2. Battle of the Alamo ............... 50

3. Plan of Mission San Antonio de Valero Church (The Alamo) . . . . 51

4. Alamo Shrine Facade ................. 52

5. San Antonio de Valero Mission Church Facade . . . . . . . . . 53

6. San Antonio de Valero Mission Church (The Alamo). . . . . . . . 54

7. Alamo Grounds .................. 55

8. Excavations in Front of Alamo Shrine ........... 56

9. Alamo Shrine Excavations at the Front Column Pedestals . . . . . 57

10. Alamo Shrine Excavations ................. 58

11. Palisade Trench .................. 59

12. Ceramic Artifacts ................ 60

13. Ceramic Artifacts ................. 61

14. Chert and Bone Artifacts ............... 62

15. Metal Artifacts ................ 63

16. Metal Artifacts ................. 64

LIST OF TABLES

Table

Page

1. Artifact Proveniences, Alamo Shrine (41 BX 6) . . . . . . . 28

2. Identification of Faunal Remains, 41 BX $6 \ldots 38$

3. Faunal Species and Proveniences, A7amo Shrine (41 BX 6) . . . . 44 


\section{ACKNOWLEDGMENTS}

The excavations in front of the Alamo could not have been accomplished in the short time allowed without the full cooperation and hard work provided by the project staff and numerous volunteers. There were also many other people who aided the project in various ways.

The author expresses his sincere appreciation to the following individuals who gave their time and otherwise provided valuable assistance, a 11 of whom contributed to the success of the project. Should anyone be omitted the author extends his apology.

The generous financial support provided by the Texas Historical Commission to aid in publication costs is gratefully appreciated.

Crew

Waynne Cox

Fred Valdez, Jr.
Research Assistance

Anne Fox, UTSA

Eugene George, AIA, Architect

Charles Long, Alamo Museum

Sam Nesmith, Institute of Texan Cultures

Curtis Tunne 11, State Archeologist

Daughters of the Republic of Texas

Manuscript Preparation

Carol Graves

Susan Rodriguez

Mary Lou Ellis

Elizabeth J. Goode

Carmel Y. Graham

Thomas R. Hester 


\section{ABSTRACT}

In March 1977, excavations were conducted in front of Alamo Shrine where flagstone paving was being replaced by the City of San Antonio. The subsurface investigations sampled and described the soil stratigraphy which has accumulated through 2.5 centuries of occupation. The distinctive soil levels contained datable cultural materials which relate to some of the major events which took place from the earliest settlement of Mission San Antonio de Valero through subsequent periods of Spanish, Mexican, and Anglo-Texan occupations. The artifact collections have provided additional information on the material culture of the different ethnic and cultural groups to occupy the Alamo.

During the excavations, a section of a trench was found in which a palisade had been set prior to the battle of 1836 . The trench backfill contained numerous battle artifacts. Also a section of the old street curb which once extended along the front of the Alamo was uncovered. In addition, excavations in front of Alamo Shrine have provided an examination of the old church foundation and footing. This was found to be in good condition. 


\section{INTRODUCTION}

Standing alone in the northeast corner of the Well Courtyard on the Alamo grounds is a small stone monument inscribed with Japanese characters. Although the monument is not explained to the public and is largely overlooked by most tourists, it is one of the finest tributes given to honor those who died at the battle of the Alamo. Inscribed on the stela is a poem, "To the Memory of the Heroes of the Alamo." Composed by Professor Shigetaka Shiga of Japan, the poem was presented to the Alamo by him and a group of students who made the journey to Texas in 1914 just for the occasion. The poetic tribute compares the stand of the valiant heroes at the Alamo with a similar struggle in Japan waged in 1567, when gallant samurai warriors stood fast against overwhelming odds and met the death of heroes.

The tragic battle fought at the Alamo, although not decisive in the overall struggle of the time, has caught the imagination of peoples not only in this country but also in many foreign lands, and that battle has become a symbol of courage and determination.

Al though the building currently referred to as the Alamo is now the Shrine to Texas Liberty, and generally regarded as a fortress shrine to the martyred dead who gave their lives there during desperate battle in the early morning hours of March 6, 1836, it did, in fact, play a much broader role in the affairs of men.

The old church structure, which is now the shrine, is the only original building still standing from a complex of buildings which once formed the Mission San Antonio de Valero. All other structures are now gone. Even the Long Barracks which houses the museum has been reconstructed upon old mission-period foundations. At the time of the 1836 battle, most of the mission buildings were still standing, although in sad need of repairs; and they were used as refuge by those 182 men who drew the line and kept their place to await destiny. The description of that battle has been told many times, and only that part which is directly related to the archaeological finds will be repeated here.

This monograph will deal principally with the Alamo Shrine and the results of archaeological excavations conducted in front of the famous building in March 1977, 141 years after the battle. Although it is recognized that the Alamo Shrine is best known as an improvised fortress which served the needs of brave defenders, it will be considered here more fully as the Franciscan mission church it was designed and built to be. Battered and misused, and sadly neglected during much of its history, the never-completed structure was, in its original design, an architectural masterpiece. Now only a remnant of the mission-builders' dreams, it is still a very impressive and remarkably well-preserved example of Spanish Colonial architecture.

The excavations in front of Alamo Shrine provided the opportunity to examine a portion of the building foundation as well as to sample the relatively undisturbed soils which 7 ie adjacent. The stratified soils tested provided a variety of datable artifacts which represent some of the most important past events which occurred at the Alamo. Beginning with the Mission period and continuing into modern times, the artifact collections include relics from Spanish, Mexican 
and Anglo-American periods; and there are military artifacts from the famous battle. In addition, the excavations uncovered a section of a palisade ditch which extended between the southwest corner of the church and the old quadrangle, forming a temporary defense during the battle.

The rare opportunity to examine the construction and condition of the historic building foundation has provided valuable structural information. The building will be described from the standpoint of the original architecture, and a study is made of the front facade in its present form along with interpretations of the planned original design. It may come as a surprise to some readers that the building facade currently seen is only the lower portion of a traditional Spanish Early Baroque retable facade, which was to be larger and to rise several feet higher than the present one; and that the curvilinear-shaped gable crowning the center top of the facade, which is shown in many illustrations depicting the famous battle, was not installed until many years after the battle when the U.S. Army occupied the old structure.

The limited archaeological excavations in front of the Alamo were allowed when the old flagstone paving was removed to prepare for the installation of a newer "Drydan" type of flagstone. This was done by the City of San Antonio as part of the revitalization of Alamo Plaza.

The excavations were confined to the area directly in front of the Alamo Shrine, between the front doorway and the southwest corner. Given the opportunity to investigate an area of Alamo grounds not previously studied, the excavations were, therefore, designed to satisfy two basic needs: (1) the testing and sampling of the soil deposits in the study zone to obtain cultural and ecological materials to better understand past events, and (2) the examination of a section of the old church foundation to record the construction and present condition.

Because of the subsurface disturbance expected during the repaving in front of the Alamo, Curtis Tunnell, State Archeologist, requested that the Center for Archaeological Research conduct the necessary excavations to make a cultural resource assessment.

Permission to excavate on Alamo grounds was generously given by the Daughters of the Republic of Texas. Legal authorization to excavate at the Alamo, a National Register Historic Site (41 BX 6), was provided under State of Texas Antiquities Permit 139. The archaeological investigations were undertaken in March 1977 by the Center for Archaeological Research, The University of Texas at San Antonio, under contract with the City of San Antonio. General supervision of the project was provided by Dr. Thomas R. Hester, Center Director. The fieldwork was carried out by Center staff archaeologists and a number of volunteers under the direction of Jack D. Eaton, Center Associate Director. 


\section{HISTORICAL BACKGROUND}

The history of the Alamo has been long and involved, spanning more than 250 years; and it has shaped the lives of many peoples with differing ethnic and cultural backgrounds through a series of turbulent historical events. The Alamo Shrine, originally a mission church, dates from 1744, when the cornerstone was laid; but it is the end product of earlier developments which began in 1700 in what is now the State of Coahuila in northeastern Mexico.

Expansion of the northeastern frontier of New Spain in the 17th century principally began with military expeditions. These were followed by the coming of the missionaries and miners, and eventually the ranchers and settlers. The Indian mission, and the military presidio often established nearby to protect the mission, were important institutions of Spanish frontier policy. The imperial policy was aimed at controlling the region and its inhabitants by a peculiar combination of armed force and gentle persuasion (Almaráz 1979:1).

Although the secular clergy generally looked after the spiritual needs of the Spanish soldiers and settlers, the mendicant friars were given the task of instructing and converting the native Americans in a plan designed to eventually produce useful Christian citizens. The establishment of Indian missions on the frontier was therefore the responsibility of the Mendicant Orders, notably the Franciscans, Dominicans, Augustinians, and the Jesuits (Jones 1974).

The Franciscans were the first mission builders (McAndrew 1969:134), and one of the areas where they ventured in search of needy souls and to establish missions was in northeastern Mexico and Texas. After establishing the Franciscan Apostolic College of Santa Cruz de Querétaro in 1683, where missionaries were trained for frontier service, the friars began venturing northward.

The appearance of French interlopers on the Texas coast in the 1680s stimulated the Spanish authorities to send military expeditions into eastern Texas (then claimed by Spain), to investigate and evict any French intruders found. Accompanying the military forays were Franciscan friars Damian Massanet and Francisco Hidalgo, who would establish Mission San Francisco de los Tejas and other east Texas missions on the Neches, Guadalupe, and Red Rivers in the 1690s (Yoakum 1855:45-46). Those making the long and strenuous journey from Querétaro to east Texas crossed changing terrain and many rivers and creeks, but there were two places along the way that the missionaries noted with special enthusiasm as favored locations to establish missions. One was near the Paso de Francia crossing the Rio Grande del Norte, and the other was farther to the north on the Rio San Antonio. Both of these locations would eventually become the sites of important missions and Spanish settlement. It was near the Rio Grande that the history of the Alamo began.

In 1699, after a short and unsuccessful attempt to operate the newly founded mission San Juan Bautista on the Rio de Sabinas north of Monclova, Mexico, Franciscan friars Antonio de San Buenaventura y 01 ivares, Marcos de Guerena, and Francisco Hidalgo, moved their new mission farther to the north to locate it in the Valle de la Circumcision, where there were freshwater springs and preferred 
Indian camps some two leagues from the Rio Grande; it is at this site that the present town of Guerrero, Coahuila, now stands. The reestablishment of mission San Juan Bautista at the new Tocation took place on New Year's Day in 1700 (Almaráz 1979:6; Eaton 1980; Weddle 1968:28).

Shortly after the mission was established, a military contingent, consisting of a small mobile cavalry unit under the command of Sergeant Major Diego Ramon, was assigned to protect the exposed mission. Soon a formal presidio was constructed near the mission, which would eventually become the core of Spanish settlement in the region.

The missionizing efforts at San Juan Bautista became a formidable task, and a second mission was established a short distance to the northwest in order to share the growing responsibilities. On March 1, 1700, the Mission San Francisco Solano was founded under the authority of commandant Diego Ramon, and Fray Antonio 01 ivares took charge. It was this mission that would eventually, through a series of moves and changes in name, become the Alamo.

In 1702, a third mission, San Bernardo, was established under the direction of Fray Alonso Gonzalez a short distance to the north of San Juan Bautista. The three missions and the presidio, located near important crossings of the Rio Grande, formed a Spanish settlement in colonial times which could be called the "gateway to Spanish Texas" (Weddle 1968). This place was the starting point for explorations, military campaigns, and northern expansion into the province of Texas. The many different Indian groups which were present at the missions have been listed and described by Campbel1 (1975, 1979).

Mission San Francisco Solano, although successful as a mission in the long run, seemed to have been plagued with an endless series of problems almost from the beginning, and it functioned at its original location for only a brief time. Subject to repeated attacks by hostile Indians, crop failures, scarcity of water, and finally abandoned by the neophytes late in 1703, the mission suffered the first of a series of failures. In October of the same year, Fray Antonio, joined by Fray Hidalgo, moved the mission 16 leagues to the west, near the present town of Zaragoza, Mexico, and renamed it mission San Ildefonso. It should be noted that mission was an "activity" more than a place or building. Thus when a mission was relocated, the "activity" was moved, but the non-portable structures remained behind (Almaráz 1979).

Mission San Ildefonso was moderately successful for several years, while the missionaries instructed the native inhabitants of the area. However, in 1708, the wild Toboso Indians of the region finally provoked the mission neophytes to flee, and the friars and their small mission were once again abandoned. Efforts were made to induce the frightened Indians to return to the mission, but without success. Then, around 1712, the Franciscan College granted permission to move the mission to a more suitable place on the Rio Grande about three leagues from its original location. The relocated mission then acquired a new name; this time it was called Mission San José (Weddle 1968:55).

Mission San José remained at the Rio Grande del Norte until 1718, when Fray Antonio, with permission of the College, moved his mission north into Texas and reestablished it on the bank of the Rio San Antonio de Padua near San Pedro Spring: The official reason for the move, as directed by the governor, was to place a 
mission and to establish a Spanish settlement at a convenient place on the Camino Real between the Rio Grande and the east Texas missions. To place a mission on the Rio San Antonio, at the place the Indians called "Yanaguana," had been a dream of the Franciscan friars for many years, ever since friars Massanet and Hidalgo had made a brief visit there in 1691 with the military expedition and had marveled at the beauty of the place and the abundant willing souls ready for harvest. Now at last the dream would come true.

In April 1718, an expedition lead by Martin de Alarcón, governor of Coahuila and Texas, and including Fray Antonio 01 ivares, left San Juan Bautista on the Rio Grande and journeyed north into Texas, arriving at the San Antonio River on May 1. They camped on the west bank of the river near San Pedro Springs; and on the same day, Fray Antonio, by permission of Governor Alarcón, established Mission San Antonio de Valero, naming it after St. Anthony of Padua and the Viceroy of New Spain, the Marques de Valero (Weddle 1968:149). Just four days later, and a short distance downstream from the mission, the governor founded the Presidio and Villa de Bejar, a small settlement which one day would become the City of San Antonio (Barker 1929: 36-38).

Shortly after the founding of the Mission San Antonio de Valero on the west bank of the San Antonio River, somewhere near the present Robert B. Green Hospital, it was moved to the east bank of the river, opposite the Presidio and Villa, which was evidently a more suitable location. This second location was about where the Chamber of Commerce building is now, across Commerce Street from Joske's. The mission buildings are described as consisting of a small fortified tower for the friars and crude huts for the mission Indians (Barker 1929:36-38; Fox, Bass, and Hester 1976:2). In September 1720, Fray Antonio retired from the mission to return to the College of Santa Cruz at Querétaro. He was succeeded by Father Francisco Hidalgo, an old friend and colleague.

Problems continued to follow the mission, and in 1724 a terrible hurricane demolished the houses of the Indians and did the mission great damage (Barker 1929:36-38). The storm was devastating, and preparations were again made for another move. This time the move was slightly upstream, on the east side of the river but still opposite Presidio and Villa de Bejar. At this final location of San Antonio de Valero, where the mission church (the Alamo) still stands, the architectural complex and settlement developed to its ultimate degree.

By 1727, the construction of a permanent mission complex was wel1 underway, and there were 70 families (about 280 persons) representing three Indian groups in residence. These included the Payayas, Xarames, and the Yerebipiamos. The Payayas were the largest group represented. A convento (friary), granary, and other structures of stone and adobe, including Indian housing and workshops, were built or were under construction (Barker 1929:36-38; Fox, Bass, and Hester 1976:3). An adobe church was also being constructed, but there were plans to eventually build a large stone structure when qualified masons were available. The mission church will be discussed in detail later.

An epidemic, probably smallpox, struck the mission in 1739 and greatly decimated the Indian population, reducing it to about 46 families (184 individuals); but by 1740 , with the conversion of the Tacamanies Indians, the mission population increased to 260 persons (Chabot 1931:62; Fox, Bass, and Hester 1976:3). By 1744, when the cornerstone for the new church was laid, the mission Indian 
population had reached 311 persons. The Indian housing at this time consisted of two rows of small houses (adjoining apartments), with adobe walls and grass thatc roofs forming a row on either side of an acequia (water ditch), and the whole complex was to be surrounded by a wal1 (Chabot 1931:62; Fox, Bass, and Hester $1976: 3)$.

The mission church, which was under construction and nearly completed by 1757 , began to crack because of poor workmanship; and by 1762 the twin towers, arched roof, Moorish dome, and upper walls had collapsed. As will be described later, a new and better-constructed church, the one standing today, was subsequently built.

In 1762, there were 275 persons, representing seven different Indian groups, at the mission (Schuetz 1966:22-24). At this time, or by 1765, the mission pueblo is described as having "30 houses of adobe;" and there were an undisclosed number of other houses of temporary character (Fox, Bass, and Hester 1976:4). What is probably meant here is that 30 Indian apartments were on the inside of the quadrangle forming around the plaza and probably also within the plaza area (Fig. 1). There was also a large granary, a two-story convento complex with its own patios, and workshops. The entire area was enclosed within a high wall, and there was a main gate entrance on the south side over which was a small fortified tower (Fig. 1).

In 1772, the control of Mission San Antonio de Valero was transferred from the College at Querétaro to the Franciscan College of Nuestra Seńora de Guadalupe de Zacatecas (Leutenegger 1977; Webb 1952:II,568). The mission architectural complex at this time had stabilized at its ultimate development. Then, in 1793, in compliance with a royal decree issued the previous year, Mission San Antonio de Valero, along with the other missions which had been established downstream on the San Antonio River, were secularized. The mission records were transferred to the Villa de San Fernando church archives, and the mission lands distributed to the resident mission Indians. This ended the role of the Alamo as a mission. Later the building complex would serve other needs.

After Mission San Antonio de Valero was secularized and abandoned, the buildings were stripped of usable items such as doors and locks (Chabot 1941:14). The buildings were essentially unoccupied until 1802 when, as a result of renewed French threat on the eastern frontier, the Flying Company of San Carlos de Parras del Alamo, a Spanish cavalry unit, occupied the old ruins (Smith 1967:8). Evidently the old mission complex became known as the "Alamo" during this occupation. In 1805, a military hospital, the first in Texas, was established at the Alamo; and by 1810 a considerable amount of repairs and structural additions had vastly improved the living and defense conditions of the complex (Nixon 1936:17, $27-28)$.

At this time the Mexican Independence movement was underway south of the Rio Grand and was soon to be felt in Texas. On January 21, 1811, a group of Mexican rebels led by Juan Bautista Casas took control of the Alamo and set up operations headquarters. The following year a larger rebel force, under the leadership of Jose Gutierrez and William Magee, entered Texas from Louisiana. After a series of victorious encounters with Spanish troops, they arrived at San Antonio de Bejar on Apri1 2, 1813, and occupied the Alamo (Garrett 1939:39-40,178; Fox, Bass, and Hester 1976:8). 
Subsequent to Mexican Independence in 1821, Mexican troops under Colonel Domingo de Ugarttechea were assigned to San Antonio and occupied the Alamo complex through the 1820s and early 1830s, but little was done to improve facilities (Yoakum $1855, \mathrm{I}: 55)$.

Meanwhile, Texas colonists were beginning to react to Mexican provincial policies backed by military persuasion, and early in 1835 protest became rebellion. One antagonistic event led to another, and when the colonists fired upon Mexican dragoons on the Guadalupe River just south of Gonzales on October 2, 1835, the Texas Revolution had begun (Nevin 1975:71).

Although the primary concern was the defense of the Mexican Constitution of 1824, which President Antonio López de Santa Anna had a11 but dissolved, there was also strong feeling by many colonists toward independence from Mexico. Sam Houston and his followers were in favor of supporting the Constitution, while opposing the dictatorship of Santa Anna, but doing so as loyal Mexican citizens. As can be seen, there was a lot of disagreement among the Texans.

In 1835, General Martin Perfecto de Cos, with two divisions of infantry including about 1400 troops, arrived and took over the Alamo. During his occupation, he had the place repaired and put into fort fashion. This included repairing walls and installing other defenses, such as additional palisades and ditches; mounting several cannon at positions on the walls; and also building a large platform about 12 feet in height, with an artillery ramp consisting of an earthen incline covered with planks to the top rear of the old church, where he placed an 18-pounder cannon (Fox, Bass, and Hester 1976:11; Weems 1971:47).

On December 5, 1835, a ragtag army of some 300 Texans, commanded by Edward Burleson, and divided into two columns, one led by Ben Milam and the other by Francis Johnson, entered San Antonio and began a house-to-house and street-to-street fight with Cos' troops. Milam was killed in the struggle, and Johnson took charge of both columns of Texans who, in spite of heavy artillery fire from the Alamo, advanced through the town. The Texans brought up their own cannon and blasted away at the Alamo walls, doing some damage and shattering the nerves of the defenders, causing 185 Mexican soldiers to desert. After five days of siege, General cos sent out the white flag and surrendered his remaining 1100 officers and men to Burleson (Nevin 1975:75). This ended the first battle of the Alamo, and the Texans took charge of the fortified complex.

General Cos and his troops were given leave to return to Mexico on the promise not to return. Although the Texans went wild with celebration at the defeat of the Mexican army, General Sam Houston, Commander-in-Chief of the Texan army, seemed to be the only one to realize that Cos' humiliating defeat would soon bring reprisals. They did not have long to wait.

When President-General Santa Anna learned of the defeat of General Cos (his brother-in-law), his response was swift. Virtually emptying Mexico's national treasury to equip an army to invade Texas, Santa Anna had assembled most of his forces at Saltillo by the end of January 1836. On February 1 an army of nearly 6000 men and 20 cannons were on the move toward Texas. By mid-February they were at Presidio del Rio Grande (Guerrero), where they rested and regrouped. Ironically, they camped just within a musket shot of the site of the old Mission San Francisco Solano, the birthplace of the Alamo to which they were soon to lay siege (Perry 1975:32; Weddle 1968:386). 
In the meantime, the Texans began to appreciate the seriousness of the situation and to realize that a Mexican army under General Santa Anna was indeed advancing on San Antonio. Although a great deal of confusion clouded decisions of what to do, it was finally decided that. the Alamo complex, the only sturdy structures available which could withstand an attack, would be repaired and put back into fort fashion as best as time and materials would allow. William Travis and James Bowie were to be joint commanders of the fortifications. Green B. Jameson was appointed garrison engineer and was responsible for fortifying the Alamo (Turner 1972:122; Williams 1933:18; Smith 1967:18-22). The quadrangle and building walls were repaired, and parapets of earth and wood were erected for cannon and riflemen. Men would also take the prone position on rooftops. In the old church, scaffolding was constructed to serve as a catwalk for riflemen; and the door and window openings were blocked off (Fig. 6,b).

Other fortifications were erected within the complex, and possibly at this time included a palisade and ditch to close off the open area between the southwest corner of the old church and the southeast corner of the quadrangle, a distance of about 110 feet. This fortification is one of particular interest, since a portion of the palisade trench was discovered during archaeological excavations. The fortification has been described as consisting of two rows of cedar posts spaced six feet apart and set within shallow trenches. The posts in each row were tied together top and bottom with rawhide strips, with the earth rammed around the base. A long, deep ditch was then dug in front on the double palisade, and the excavated earth was packed between the rows of piles (Chabot $1941: 24$; Smith 1967:21). This type of provisional fortification has a very long history and has been described for military use since the Middle Ages (Hoyt 1811; Wheeler 1898:161-175), and it is still occasionally used. The actual height of the Alamo palisade is not documented, but probably looked much like that shown in Fig. 2. Behind this fortification were placed four 4-pounder cannons. According to legend, David Crockett and his Tennessee Boys were assigned to defend the palisade (Williams 1933:13).

Although there were 20 or so cannons of various sizes at the Alamo, only about 18 were serviceable. In addition to the four cannons at the palisade, an 18-pounder was mounted on an earthen platform with ramp at the southwest corner of the quadrangle. There were three 8-pounders on the north wal1, a 12-pounder (possibly two) on the west wall, three 12-pounders on the elevated platform within the old church, and a small cannon of undetermined size (possibly l-pounder) on top of the two-story long barracks. Also there were two 8-pounders placed on a low plat. form within the south-center area of the quadrangle facing the front entrance, and two 6-pounders in the lunette just outside of the main gate on the south side (Smith 1967:18). Small arms (muskets and pistols) used by the Alamo defenders varied in size, type, and manufacture. Some shoulder weapons were percussion, but most were evidently flintlocks firing lead balls, with calibers ranging from .36 to .70 inches.

The fortifications and weapons at the Alamo were not ideal to withstand a formida. ble siege, and the 182 men who would be the final defenders were far too few to adequately man such a large area (the area of just the quadrangle was about 2 acres, and more than one-third of a mile of perimeter for the whole complex had to be defended); but the decision was made to stand, despite the odds. 
On the morning of February 23, the Mexican forces entered San Antonio de Bexar and began deploying their divisions. Having sighted the approaching army, the Texans withdrew into the fortifications of the Alamo. A column of Mexican infantry entered Main Plaza with orders to take San. Fernando church and to display the red flag on top of the spire, signifying no quarter to the enemy. A cannon shot from the 18-pounder at the Alamo thundered the Texans' response.

The Mexican artillery commander was ordered to immediately set up his two 8-inch howitzers and to fire four grenades (spherical case) into the Alamo. Fragments of spherical shells were found during the archaeological excavations. The exploding shells, although doing little actual damage, had definite impact on the defenders, and a white flag was displayed. The artillery ceased firing, and Travis dispatched a written communication addressed to the commander of the invading forces stating that he wished to enter into agreements. Receiving the message, General Santa Anna gave the verbal reply that he would not deal with bandits and that they had no alternative but to surrender unconditionally (Perry 1975:38-39). The demand to surrender was rejected by the defenders of the Alamo, and the stage was set for an all out confrontation.

On February 29, the siege of the Alamo began. Batteries of 8-pounder cannon and 6 -inch and 8-inch howitzers were placed into position across the river and beyond effective musket range, and bombardment of the fortifications commenced. Cannon mounted at the Alamo returned fire, but evidently did no great damage.

The next day Mexican soldiers began crossing the San Antonio River to within small arms range, and for the following nine days, through March 5, the siege continued, with bombardment by field pieces and small arms fire.

On March 5, the general order for the assault was issued by General Santa Anna, after consulting with his field conmanders. It would be carried out the following morning.

The initial attack formation, which was probably assembled in Main Plaza, consisted of four marching columns as well as ready reserves, a combined force of about 1500 men. In addition, cavalry was assigned to prevent anyone escaping (ibid.). The first column, commanded by General Cos, included a battalion from Aldama and three companies from the San Luis contingent; it was to advance on the western front of the Alamo compound which faced the city. The second column, under Colonel Duque, consisting of his own battalion and three companies from San Luis, was to go against the north wall. These first two columns totaled about 700 men. The third column, under command of Colonel Romero, was formed of two companies of fusiliers (infantry) from the Jimenez and Matamoros battalions, more than 300 men, and was to attack the east wa11, including the back of the church. The fourth column, made up of over 100 chasseurs (light infantry) commanded by Colone 1 Morales, was to assault the main entrance to the quadrangle on the south side, and also the palisade fortification set between the southwest corner of the church and the quadrangle. Held in reserve, but soon committed to battle, were about 400 men of the sapper battalion (engineers) and five grenadier (elite infantry) companies commanded by Colonel Amat (Perry 1975:45-46). Other reinforcements which considerably increased the attack force would also be employed.

The advance began at one o'clock in the morning of March 6. By three o'clock the columns had reached the river and were crossing over by some narrow wooden bridges. Then, at dawn's first light, a bugle call ordering death, the dreadful deguello, 
urged the attack to move more rapidly and to close for final assault on the defenses. The raging, bloody battle that followed was over by eight o'clock in the morning, and all of the 182 Alamo defenders perished in the fight, but at a staggering. loss to the assault forces. The last to resist were those who held out in the old mission church, now the Alamo Shrine.

As a result of the battle, the buildings and walls of the Alamo complex had suffered considerable damage. When the Mexican Army moved out of San Antonio, General Vicente Filisola, second in command under Santa Anna, sent orders to General Andrade to demolish the Alamo's fortifications and spike the guns, "rendering them useless for all times," then to proceed to join the main army at Goliad (Fox, Bass, and Hester 1976:12). This was carried out by the soldiers to the best of their abilities during May 22-24, 1836, by leveling all single walls, tearing up and burning the wood palisades, and filling all open trenches. The section of palisade trench found during the archaeological excavations had been backfilled at this time. Some of the main structures, including the old church, had been built much too sturdily to be easily destroyed and therefore were left standing. Al though an attempt was made to burn the church by setting fire to the wood artillery ramp and platform on the inside, little additional damage was actually done,

Following the departure of the Mexican troops, the Alamo lay vacant and unclaimed for several years. Then, on January 13, 1841, by an Act of the Congress of the Republic of Texas, it was declared that the Alamo property would belong to the Roman Catholic Church (ibid.).

The United States Army took an interest in the Alamo ruins when Texas was annexed to the United States in 1845 and involvement in the Mexican War in 1846 created a need for more military installations in the borderlands. Because of its location and commerce, San Antonio was selected as headquarters for the Eighth Military District. On January 2, 1849, Major E. B. Babbitt, acting Quartermaster, took possession of the remaining Alamo buildings, which the army leased from the Catholic Church. The buildings were repaired at considerable expense to serve as a U.S. Army Quartermaster Depot, which would freight supplies from the port of Indianola through the Alamo depot and on to other Army posts (Corner 1890:10). It was during the Army repairs to the buildings that the curvilinear gable was constructed on top of the old church, along with installing upper flooring, windows, and a new roof (Smith 1967:25).

With the Army occupation, houses and commercial enterprises began to Tine Alamo Plaza, and Menger opened his hotel next to the Alamo Depot in 1859 .

Shortly after commencement of the Civil War in 1861, the Alamo was seized by secessionists and became a Confederate Army depot. During this time the old church caught fire, and the entire interior, including the wooden roof, burned; the building had to again be completely repaired.

The Alamo remained in Confederate hands until the War's end, when it was returned to the United States Army in 1865 (Fox, Bass, and Hester 1976:21). The U.S. Army continued to occupy the Alamo Shrine until 1879, when it moved the depot to the new Fort Sam Houston Quadrangle.

The Alamo buildings that were not used by the Army were essentially left unoccupied until 1877, when Honore Grenet bought the old Long Barracks and its courtyard from 
the Catholic Church and converted it into a store and warehouse (ibid.). The remains of the other buildings had by this time been demolished.

In 1883, the State of Texas bought the Alamo Shrine from the Catholic Church, and in the same year the Grenet building was sold to the Hugo and Schmeltzer Company and further developed as a department store (Fox, Bass, and Hester 1976:23). By 1889, with the development of streets and sidewalks, along with more houses, shops, restaurants, and saloons around Alamo Plaza, the character of the area changed. The old street curb uncovered during archaeological excavations was installed at that time.

In 1905, the State of Texas purchased the Hugo and Schmeltzer property and, along with the Alamo Shrine previously bought by the State, designated the Daughters of the Republic of Texas as guardians of the Alamo properties (ibid.). Eventually, through the 1920s and 1930s, the old remaining buildings on Alamo grounds were restored to their present condition. In 1934 the area in front of Alamo Shrine was widened to form the ceremonial square, and in 1940 the Alamo Cenotaph 10cated in the Plaza was dedicated.

During the 280-year history of San Antonio de Valero (the Alamo), from its beginning as a small Indian mission in northeastern Mexico to its present status as a national shrine, the Alamo has gone through a remarkable series of locational changes, with nearly as many changes in name; additionally, it has experienced an astonishing variety of manipulated uses far beyond its initially designed purpose as a mission. But in spite of its long, insecure, and troubled past, the Alamo, al though not by intent, has gained a notable international recognition based upon a heroic but tragic event which occurred within a few days of its centuries-old existence. 


\section{THE ARCHITECTURE}

San Antonio de Valero was typical of Spanish Colonial Indian missions with regard to layout and function. As a frontier institution and a vital feature of Spain's pioneering system, the mission was charged with the responsibility of Christianizing and instructing the native peoples with the intent of eventually producing useful citizens under the Spanish Crown (Bannon 1964; Bolton 1907).

Basically, the Indian mission was a Christian seminar and industrial trade school. The mission architectural complex was, therefore, comprised of buildings which housed these functions. Although each mission on the frontier of New Spain had its own distinct layout, and no two seem to have been built exactly alike, the basic architectural components were always there.

Fundamentally, the mission complex at San Antonio de Valero consisted of a church, convento (friary), granary, workshops, storerooms, and Indian housing. These facilities were contained within a walled enclosure (Fig. 1). This was designed not only for organization and control of the neophytes, but also for defense on a wild frontier. In organization, the church and convento represented the spiritual and administrative center of the mission, while the Indian housing and workshops formed the social and industrial complex. Also belonging to the mission was 1 and nearby for agriculture and pasture.

This report will be primarily concerned with the mission church, the most formal and traditional architectural component within the mission complex. Of all the original buildings which once comprised Mission San Antonio de Valero, only the church (Alamo Shrine) remains standing.

Construction of Mission San Antonio de Valero at its final and present location was well under way by 1727 . However, due to the shortage of building materials and unavailability of qualified masons, the large stone church suffered delays in construction; and it was not until May 8, 1744, that the cornerstone was laid (Bolton 1907: 297). In the meantime, a simple adobe structure, and later, the granary, were used as a temporary church.

The first attempt to construct a large masonry church failed. The church which was begun in 1744 was actually completed, including an arched roof, a dome, and a bell tower; but sometime in the early 1750s it collapsed due to poor workmanship and materials (Fox, Bass, and Hester 1976; Habig 1977; Schuetz 1966). Then, about 1756, reconstruction of the church was undertaken, this time under the direction of a Master Builder. Good building principles and materials were used, and the result was a sturdy structure, most of which remains standing today. The architect or Master Builder who designed and built the church is currently unknown. However, it was Fray Francisco Hidalgo who requested that the church be built and who undoubtedly closely supervised its construction. Inscribed on the decorative keystone above the front doorway is the date, 1757, which probably commemorates the building construction. Unfortunately, the records are not clear on this point, and the church was not completed prior to secularization in 1793.

In plan, the church was laid out in cruciform (Fig. 3) and is 35 Spanish varas $(28.75 \mathrm{~m})$ long, floor dimension (varas $=0.84 \mathrm{~m}$ or $2.75 \mathrm{ft}$.). There is a large nave 9 varas $(7.60 \mathrm{~m})$ wide for the congregation, a broad transept 17.5 varas $(15 \mathrm{~m})$ 
across where there were to be side altars, and a sanctuary and apse where the main altar was to be placed. The church floor was probably paved with flagstones. The church was to have a domed (barrel vault) roof supported by stone arches. Over the transept was to be built a large cupola supported by four arches, and above the front entrance was to be a choir loft. The stone arches rise from pilasters which are simple in design, with multielement basal and spring molding. Although nearly all of the arches were installed, there is no clear record that the roof, cupola, or choir was actually completed before work on the building ceased (Leutenegger 1977).

The sacristy, where the priests prepared for services and stored ceremonial objects, was located on the north side of the church nave adjacent to the transept. Originally, the sacristy was about three meters longer in the north-south axis than it is presently (Fig. 3). The long room was divided by an arch, and each section was roofed with a rib vault. The room has three doorways: one entering the transept, another to the adjacent room, and a third opening to the convento patio (We11 Court). There were also two glass windows with iron gratings (Leutenegger 1977).

The large room adjacent to the sacristy, currently called the Monks Burial Ground, was possibly planned originaliy to be the rectory, but it appears to have had various other functions in the past. While the church was under construction, the large sacristy was used for the church services, and the room adjacent (rectory) served as the temporary sacristy. There is no clear indication in the records that the church proper, which was never completed, was ever used for regular services. The large room designated to be the sacristy probably continued to be the focus of church services until final abandonment.

Flanking the church entrance are two small roams which were the bases of two towers planned but probably not completed. The north room was possibly the confessional, while the one on the south side was the baptistry. Each has a splayed doorway and window. The planned towers were to support four bells (Habig 1977). It is probable that a small upper window was to be placed in each tower.

The foundation upon which the church rests consists of a thick wall, built of large irregular stones and lime mortar, set in a footing trench. A description of the foundation is given in the section of this report dealing with the excavations.

The walls of the church building are very sturdy and are more than 1.25 varas $(3.5 \mathrm{ft}$.) in thickness. They are constructed of rough masonry, consisting principally of irregular-shaped stones set in generally uneven coursing and laid with sand-lime mortar. The facings of the stones, both inside and outside of the building, have been dressed to provide flat surfaces, and chisel marks are plainly visible. Remains of lime plaster can also be seen. The corners of the building are ashlar and plumed. In contrast to the rough construction of the building walls, the center facade is constructed of carefully cut and dressed ashiar nicely fitted to form a beautiful composite. The limestone blocks used in the construction are said to have been mined locally (ibid.).

The building, except for the front facade, is plain in design and has been describel by the friars as Tuscan workmanship (Leutenegger 1977). There is a simple threeelement molding about 1.1 meter above the present ground surface, extending along the front of the buildings and around the base of the south bell tower. Apparently the rest of the building was without molding. 
The front facade of the church is traditional for the times and is quite ornamental (Fig. 4). This is called a retable facade. Its basic design and occasional function were similar to the large retables (retablo major) placed behind the main altar of a church, with niches to display statues of saints and other religious objects and symbols, planned to lead the eye to points of emphasis. This type of retable facade is of the late 17 th and early 18 th century Mexican Baroque style (Baird 1962; Markmann 1966; McAndrew 1969).

Flanking the ornamental arched doorway, with floral designs and its geometrically paneled wooden doors, are four collateral columns and two niches for statues. The niches, which are of classical derivation, have arched tops with a scalloped shell pattern and segmented, floral-decorated side panels. Each niche has a concave interior and a projecting, semicircular podium base for supporting statues of saints. The columns, which are also classical in inspiration, are combined fluted and salomonic (twisted) shafts with corinthianesque capitals. The bases of the columns rest upon tall pedestals, each decorated with what appears to be a floral design. Directly above the doorway is a large window framed in ashlar which once lit the choir loft. Flanking the window are two more niches for statues similar to the ones below. The upper portion of the facade (as currently seen with its top curvilinear gable) and the two upper side windows (Fig. 6,C) were late additions completed by the U.S. Army in 1849 when the old damaged building was repaired to serve as a Quartermaster Depot (Fox, Bass, and Hester 1976).

The remaining original facade (Fig. 6,c), which is located below the U.S. Army addition, and which may be al1 that was completed before secularization, is 8.3 varas $(7 \mathrm{~m})$ in height. (The total height of the present building with its later addition is $10.5 \mathrm{~m}$.) However, the planned total height of the facade (Fig. 6,a) was to be 14.3 varas $(12 \mathrm{~m})$ from ground to its highest point (Leutenegger 1977). In other words, it was originally planned that the center front of the church would actually rise about 1.5 meters ( 5 feet) higher than the present structure.

In the original plan, columns were also to flank the second level niches; and a fifth niche, probably also flanked by short columns as was the scyle for retable facades of its time, was to be centered above the choir window (Fig. 5). Since the upper part of the church was not completed prior to secularization, it is doubtful that the upper portion of the facade was actually finished.

In the lower two niches were placed statues of St. Francis and St. Dominic. In the two niches above, statues of St. Clare and St. Margaret of Cortona were to be placed; the top niche was to display a statue of Our Lady of the Immaculate Conception. The lower two statues were installed before secularization, but those for the upper niches may never have been completed. The reconstruction drawings shown in Figs. 5 and 6 , a are based upon contemporary descriptions and planned works given in the inventory records by Fray Pedro Ramirez in 1772, when control of the mission was transferred from the Franciscan College at Queretaro to the College of Zacatecas (ibid.).

Following secularization and eventual abandonment of Mission San Antonio de Valero, along with the other San Antonio missions in 1793, the buildings fell into disrepair and were stripped of usable items, such as doors, windows, and hardware. The mission lay essentially unoccupied until 1802, when a company of Spanish cavalry, the Segunda Compania Volante de San Carlos de Parras del Alamo, so named after the town in Mexico near where they were previously stationed, occupied the 
deserted mission complex. Apparently this was when the name "Alamo" was firmly attached to the old buildings. During the occupation by the cavalry, the mission church (sacristy) was once again used for religious services. This time it served as parish church for the soldiers and their families, with their own pastor, until 1810 when the place was once again abandoned (Habig 1977). Later it would serve other uses, but would never again be formally used as a church.

During 1821 to 1835, when the Mexican Army occupied the old mission complex, 1ittle was done to improve the church structure (Fig. 6,b). During the reoccupation of the Alamo by the Texans in 1835, and through the siege of 1836, no repairs were made to the old chapel other than to block up door and window openings and to construct an interior scaffold for riflemen (Smith 1967). It was not until the U.S. Army occupation in 1849 that a frame gable roof was installed, along with repairing the upper walls, adding the top center gable, cutting new upper windows, and installing upper flooring (Fig. 6,c). In 1920, a new timber-framed gable roof with shingles was constructed by the Daughters of the Republic of Texas after acquiring the famous structure. Then, in 1934, concrete vaults covered with leadcoated galvanized metal with standing-seam roof replaced the frame structure. The flat roofs over the tower bases and adjacent rooms are covered with the same material in a flat-locked seam. This roofing is still in use.

Of comparative interest, each of the five missions established along the San Antonio River have church facades, as well as plan and construction, which differ in form and tradition. As already noted, Mission San Antonio de Valero Church (the Alamo) is cruciform in plan, was to have two bell towers, and has a retable facade in the Early Baroque style. At Mission Nuestra Señora de la Purísima Concepción (1740) the church is also cruciform, has two bell towers, and the retable facade is Plateresque, a later style following the Baroque in Mexico. And at Mission San José y San Miguel de Aguayo (1768), the large church is 1 inear without transept, has only one bel1 tower, and the facade is an even later retable style, the Ultra-Baroque or Churrigueresque. The small church at Mission San Francisco de la Espada (1740) is cruciform in plan. It has an espadaña (wall pierced with arches in which bells are hung) above a plain facade with a moorish arch doorway.

Mission San Juan Capistrano church is linear with no transept. Along the west wall of the church are remnants of a series of arches, but otherwise it has a plain facade. The bell tower consists of a simple espadaña similar to that at Mission Espada; however, it is placed perpendicular to the end of the building and above the long axis wall facing the plaza. 


\section{PREVIOUS ARCHAEOLOGICAL INVESTIGATIONS}

During the past 12 years, several archaeological projects have been conducted on the Alamo grounds, each providing valuable information to aid in better understanding of past events (Fig. 7). The WPA excavated extensively on the Alamo grounds in the 1930s, mostly in the area east of the church and convento where there had been commercial buildings earlier. However, no records of these early excavations have been found.

During summer 1966, John Greer (1967) directed excavations for the Witte Museum on the north side of the Alamo Shrine, in what had been the original mission convento patio areas. Excavations were conducted in several selected areas within what are now called the Well Court and the North Court (Fig. 7,a).

Two test excavations verified that the present wall, built in 1913 and dividing the two courtyards, rests upon an earlier wall probably of the mission period. In the North Court, Greer (ibid.) also uncovered the remains of what might have been either the original north wall of the second patio, or some other structure remnant, which was built of roughly cut limestone blocks set in a yellow sand mortar. This in turn rested upon a footing of rubble limestone laid with brown mud mortar. The wall lay several feet south of the modern boundary wall and may have been part of the original mission workshop rooms. An impressive collection of military artifacts associated with the wall suggests that it was used during the siege of 1836. Included in the collection were such items as gun parts, musket bal1s, cannon or howitzer ba11 fragments, sherds of earthenware, and other materials from that period.

Also in the same courtyard, near the southwest corner, excavations uncovered the remains of a flooring laid with sandstone slabs, as well as a portion of northrunning stone slab wall which appears to extend perpendicular from the east-west patio dividing wall. This stone construction probably dates to the Spanish period, and may be a remnant wall of one of the rooms in the old north patio described by Fray Francisco de los Dolores in 1762 (Schuetz 1966), where weaving looms and storerooms were located during the mission period.

Excavations in the We11 Court uncovered some buried structural remains of particular interest. Just east of the well, in about the center of the patio and lying below a surface of sandstone slabs laid in the Spanish period, the excavations revealed the remains of what appeared to have been a room. Only the wall base was found, but enough remained to determine construction and orientation. The walls were built of large adobe bricks set in brown mud mortar. These were laid upon the sterile black clay, which appears to have been the pre-mission period ground surface. The room flooring was puddled adobe. Only the northern end of the room, including the two corners, was excavated. The inside dimension of the exposed portion of the room measured about 13 feet. The structure is oriented about 45 degrees off north, in contrast to the approximate 9.5 degrees east of north orientation for the later church (Alamo Shrine). Possibly this structure dates to the initial building period (ca. 1727) at the site. It might have been part of the older adobe church which was mentioned by Father Ortiz in 1745, but which had fallen sometime prior to the construction of a new church of stone and mortar (Schuetz 1966:9). However, the exact location of the first church does not seem to be documented. 
Continued excavations in the southeast corner of the Well Court near the church uncovered other features of interest. A cement-covered pipe, possibly a sewer facility for the Hugo and Smeltzer store (1886), was uncovered. Beside the pipe, in deposits cut by the pipe trench, was a thin zone of artifacts, including sherds of white-paste earthenware, musket balls, and cannon ball fragments. This material might date to the partial destruction of the mission buildings by the Mexican Army in 1836, following the battle.

Also uncovered in the same area were the remains of a brick-paved surface. The handmade bricks are adobe-like in construction, laid in a coarse sandy mortar with light pink mortar between the bricks. After they had been laid, the bricks were coated with a thick, dark red slip. Probably this surface was a patio or walkway built during the Spanish period.

In 1970, excavations were carried out north of the Daughters of the Republic of Texas (DRT) Library building by the Texas Archeological Survey under the direction of William M. Sorrow (1972). Uncovered were 19th century structural footings and part of the old mission period acequia, called the Alamo ditch, which ran on the east side of the church (Fig. $7, b)$.

Mardith Schuetz (1973), then with the Witte Museum, did some extensive excavations in the North Court (second patio) in 1973, providing additional structural information for that area. She uncovered what were believed to be the remains of the original walls on the north and east sides of the convento patio, and also structural remains of what appears to have been the wall footing of four rooms on the eastern side of the patio (Fig. 7,C). She has suggested that these were the rooms for weaving and fabric storage mentioned by Fray Mariano Francisco de los Dolores during his inspection of the mission in 1762 .

In 1973, Thomas R. Hester, of The University of Texas at San Antonio (UTSA), carried out excavations east of the museum and souvenir building, testing on each side of the ditch which approximately follows the old mission period acequia (Adams and Hester 1973). These tests not only verified the location of the old ditch, but also uncovered considerable debris from several late 19th and early 20th century commercial structures which once stood on that part of the Alamo grounds (Fig. 7,d).

In summer 1975, Anne A. Fox and Feris A. Bass, Jr., with CAR-UTSA, directed excavations in Alamo Plaza, within the small park in front of the Alamo Shrine (Fig. 7,e), in an effort to locate the mission quadrangle south wall (Fox, Bass, and Hester 1976). Although all of the south wall of the original compound had been destroyed, the excavations revealed the damaged remains of the wall footings and other structural remnants.

During the early mission period at San Antonio de Valero (between 1724, when the mission was relocated to its present location, and for sometime after the 1756 inspection by Fray Ortiz), there does not appear to have been a wall around the mission. However, in the 1762 report by Fray Dolores (Schuetz 1966), he describe a wall (including a gate with a tower) which was built around the plaza. This added to provide better protection from Indian raids, which were becoming more frequent. The area outside of this wall, particularly around the gate, appears to have been a trash dumping area. 
Excavations in the area of the gate by Fox and Bass have sampled the old trash dump, providing a collection of artifacts dating from both the mission period and from subsequent Mexican and Anglo-Texan periods of occupation. In addition, remnants of what appear to have been a fortification ditch were found outside of the wall gate, just to the south; they probably date to the battle of 1836 . A number of musket balls of this period were found in the bottom of the ditch, which tends to support this conclusion.

In January 1977, Anne A. Fox monitored backhoe trenching in front of the Long Barracks (the old convento); the work was sponsored by the City as part of the Alamo Plaza repaving project. The trench was dug parallel with and just out from the front wall of the building, and extended nearly the length of the structures. In addition, a trench was dug perpendicular to the building wall to observe the foundation (Fig. 7,f). The results of this inspection indicate that the present restored wall of the Long Barracks sits upon the original convento wal1. The ground level at the time of the restoration lies about $50 \mathrm{~cm}$ below the present street level. The original wall footing, which is constructed of large, roughly formed limestone blocks, is typical of Spanish construction. Upon the footing are the remains of a wall of cut limestone blocks rising approximately $65 \mathrm{~cm}$ high. Apparently this is all that remains of the original convento wa11, and upon this the modern wall was constructed.

More recently (1979-80), excavations were conducted on Alamo grounds by Anne Fox where remnants of the original north patio wall were located. In addition, excavations by James Ivey on the west side of Alamo Plaza uncovered a section of the old mission quadrangle west wall and rooms. Reports on these excavations are currently in preparation. 


\section{THE ALAMO SHRINE EXCAVATIONS}

During March 1977, excavations were conducted in front of the Alamo Shrine by the Center for Archaeological Research under the direction of the author. The excavations had two basic objectives: (1) to examine the old mission church foundation and to record the actual construction and condition of the masonry, and (2) to note the adjacent soil deposits and collect related diagnostic artifacts. Both objectives were accomplished and provided additional information about Spanish Colonial architecture and subsequent historical events.

Twelve excavation units were dug in the test area, which was located between the building front doorway and the southwest corner (Fig. 3). The excavation units consisted of $1-\mathrm{m}^{2}$ and $1.5-\mathrm{m}^{2}$ test pits selectively placed both along the building wall and out from the wall. A shallow, backfilled palisade trench dating to the 1836 battle was also excavated. Testing was confined to the area between the church wall and the old street curb, a width of three meters. This is the area of the old flagstone sidewalk built in 1889 which was subsequently covered by the ceremonial square built in front of the Shrine in 1934. This zone just in front of the Shrine appears to have been much less disturbed than the area farther out.

Horizontal control of the excavations was maintained in relation to the building wall and southwest corner. Vertical control was related to the pre-excavation paved surface (removed by the City), which was clearly marked on the lower part of the wall and ultimately tied to the top member of the facade lower molding, a reference point (1.40 ft. above primary datum) for the 1975 Alamo Plaza excavations.

\section{The Excavations}

In all excavation units, except for those where a pipe trench ran along the front of the building and where the palisade trench extended perpendicular from the wall (Fig. 3), the soil stratigraphy was essentially the same. The pipe trench, which contained an old 1-inch iron water pipe, was about 30 to $40 \mathrm{~cm}$ wide and varied from around 10 to $40 \mathrm{~cm}$ in depth. The trench backfill consisted of mixed materials from at least three or four soil levels. The palisade trench fill, in contrast, was a conglomerate of mixed earth and debris. It appears to have been collected from the ground surface when the palisade was pulled down and the trenches backfilled shortly after the famous battle of 1836 .

The excavation units were grouped in two closely related areas along the southern half of the west wall of the building (Fig. 3). The first group, consisting of Units 1, 2, 3, and 5, was located in the zone just to the south of the building's main entrance. Unit 4 and Units 6 to 12 were situated in the area of the southwest corner of the building. Units 4,6, and 8 were placed against the building wall, and the other units extended out from the wall.

During the excavations in front of Alamo Shrine, several distinctive soil levels were encountered. The upper levels, which contain cultural materials, were deposited during the long history of site occupation. The underlying soil levels, 
which are undisturbed and culturally sterile, were formed by natural alluvium de. posits and earlier soil developments. All of these soil levels will be briefly described with mention of any cultural material contents. More detailed descriptions of the collected artifacts and bone will be presented in following chapters,

The stratified soil levels encountered, in descending order from just below the removed flagstone, include the following: limestone gravel fill, white caliche earth fill, gray to brown soil, more white caliche earth fill, dark brown clay loam, dark reddish-brown clay loam, brown to gray granular caliche, and basal white caliche. The levels of loam and bottom caliche are natural, undisturbed soils.

\section{Gravel Fill}

The flagstone paving and most of the underlying gravel fill had been removed to a depth of around $20 \mathrm{~cm}$ by the City before the project was started. When the excavations began, 3 to $4 \mathrm{~cm}$ of small sized, crushed limestone gravel still remained over packed calcareous earth (caliche) fill in some places. The gravel comprised the first excavation level (Level A) for Units 1, 2, and 5; however, Level A for the other units, where the covering gravel had been previously removed by the City, began with the upper level caliche. A description of caliche soils will be given below.

Found within the overlying gravels, but principally collected from the surface of the caliche that the gravel covered, were a variety of artifacts. Included were square iron nails, potsherds representing a variety of wares, window and bottle glass fragments, corroded metal objects, a few small chunks and flakes of chert, and fragments of red ceramic tile or bricks. The pottery collection was a mixed lot of Mexican and English wares, and also red-painted utility wares. The collected artifacts, in general, appear to be 19th century. Some items might have been in the gravel fill, but others were probably debris on the underlying surface. Evidently the gravel had been deposited just prior to the laying of the flagstone sidewalk in 1880, and again in 1934 when the overal1 flagstone paving for the present front ceremonial square was laid.

\section{Upper Caliche Fill}

Below the gravel fill was a packed level of off-white to cream-colored caliche earth with small stones and cultural material inclusions averaging about $20 \mathrm{~cm}$ in depth. It is possible that this fill was deposited about the time of the Spanish cavalry occupation between 1805 to 1810. Within this level were inclusions of small stones, fragments of red tile or brick, square iron nails, bottle and window glass fragments, potsherds, and scattered fragments of charcoal. Also present were some land snail shells (Rabdotus sp.). Pottery fragments in this level included Spanish Colonial, Mexican, English, and probably Indian wares. Basically, the artifacts recovered from this level indicate deposit during the early 1800s, and possibly with continued admixture of materials by Spanish, Mexican and Anglo occupations. 
Post holes were noted in Units 1, 3, and 12 (Fig. 9). In Unit 1, the outline of a post hole of $23 \mathrm{~cm}$ diameter filled with brown soil was exposed at the top of the level. It is located $24 \mathrm{~cm}$ away from the building wall and was found to penetrate to a depth of $50 \mathrm{~cm}$. The post hole in Unit 3 was basically of the same description and was located $1.16 \mathrm{~m}$ from the building. The post hole found in Unit 12 was located $1 \mathrm{~m}$ from the building, off the southwest corner and in 1 ine with the hole in Unit 3. These holes possibly had been dug by the U.S. Army under the direction of Major E. B. Babbitt, Acting Quartermaster U.S.A., in 1849 to install scaffolding posts for the repair of the building.

\section{Gray to Brown Soil}

Just below the packed caliche level was a deposit of light gray to brown clayey soil averaging about $4 \mathrm{~cm}$ in depth with thin lenses of light gray earth. On top of this level were many fist-sized and larger stones. Recovered from the level were potsherds of majolica, Goliad, and plain wares; bottle glass fragments; animal bones; fragments of charcoal; and a flagstone fragment. This level appears to date to the Spanish Colonial period of occupation.

\section{Lower Caliche Fill}

Below the gray brown soil was a deposit of off-white calcareous earth (caliche) roughly 10 to $15 \mathrm{~cm}$ in depth. This is a packed caliche fill similar in color and composition to the upper level. Artifacts recovered from this deposit include sherds of majolica, Goliad, and plain wares; square nails; bottle glass fragments; and animal bones. This level evidently dates to the Spanish Colonial mission period.

\section{Dark Brown Clay}

The caliche level lies on top of firmly packed dark brown clay which appears black when first exposed. It extends roughly $20 \mathrm{~cm}$ below the caliche level to where it gradually changes to a dark reddish-brown clay. There is no clear level distinction, as the color changes with depth when viewed in sunlight.

This soil is a component of the Patrick series, a member of the Venus-Frio-Trinity soils association as described by the U.S. Department of Agriculture (Taylor, Hailey, and Richmond 1966:26-27). It is a dark brown calcareous clay loam, almost black in appearance when moist. It has a substratum of red-brown clay loam overlying calcareous soil known locally as caliche. The calcium carbonate in this subsoil increases with depth.

In the upper few centimeters of the dark brown clay, the excavations recovered majolica, Tonalá, and Goliad pottery fragments; chert flakes; tool forms and arrow points; and numerous animal bones. Below the thin deposit of artifacts, the clay was culturally sterile. In the upper part of this level, where the artifacts and bone were concentrated, there were many snail shells (including Rabdotus, Practicolella and Helicina species). Below the cultural level, the number of shells rapidly diminish with depth. The top of the dark brown clay, which 1 ies about $40 \mathrm{~cm}$ below the upper white caliche level, appears to have been the early mission period ground surface. 
In Unit 5, a smal1, shallow fireplace which lay on the brown clay surface close to the building foundation was uncovered. No hearth stones or artifacts were associated, but there was a thin deposit of charcoal and ash, and heat-colored red clay in a semicircular pattern. Apparently the original fireplace was a larger subcircular pattern which was cut through when the builders dug the footing trench into the ground surface.

In Unit 8, found lying upon the brown clay mission-period ground surface, were cow or bison bones and two chert arrow points. The points were small triangular types characteristic of those found at other missions in south Texas and northern Coahuila and are evidently associated with the mission Indians (Hester 1977). Chipped stone tools and some chipping debris were also found in other excavation units at this same level.

Almost coincidental with the beginning of the reddish brown clay, a heavy deposit of river cobbles was encountered (Fig. 8). The first impression was that perhaps the stones were associated with the earlier church construction that had collapsed. However, since the stones lay in sterile clay well below the mission period ground surface, they may represent natural deposit.

\section{Basal Caliche}

Roughly $50 \mathrm{~cm}$ below the dark brown clay surface and lying just below the reddish brown clay, a level of grayish brown granulated sterile caliche was encountered. This deposit is about $15 \mathrm{~cm}$ in depth and rests upon hard white basal caliche. This is the basal footing upon which the church foundation was set. In other words, the foundation footing trench had been dug approximately $65 \mathrm{~cm}$ below the mission ground surface to reach suitable stable caliche base.

The term caliche is of Spanish origin, from Latin calx, meaning lime, and is commonly applied in North America to a porous, earthy calcium carbonate containing impurities of soil, sand, and gravel, which occurs widely at the surface or at shallow depth in the soil or penetrating porous rock outcrops in the zone of weathering (Price 1933:500). In a broad sense, caliche is used as a generic term for all types of soil-mineral accumulations. Here we will be referring to calcareous caliche, the accumulating of calcium carbonate in the soil processes which occur abundantly in south Texas.

\section{Palisade Trench}

During the excavations, a section of backfilled palisade trench dating to the famous battle of 1836 was uncovered and tested. This was first discovered in Unit 8, which was dug against the building wall and followed by means of Units 10 and 11 extending out from the wal1 (Figs. 10, 11).

The old backfilled trench was first noted as a slight depression and soil color change within the upper level white caliche. The trench began about $65 \mathrm{~cm}$ out from the building wall and extended southwest (250 magnetic) to as far as the old sidewalk curb, located three meters from the wall (Figs. 3, 11). The trench did not follow beyond the curb since that was the area of the old street and was very much disturbed. The trench averaged $\mathrm{ca} .70 \mathrm{~cm}$ in width and $\mathrm{ca} .45 \mathrm{~cm}$ in 
depth. The fill consisted of mixed soil types including caliche, but generally dark gray to brown in color with inclusions of artifacts and many animal bones. The artifacts included a variety of lead and bronze balls, ranging from pistol and musket balls to large canister shot. Two large fragments of 8-inch howitzer spherical shells (bronze), one exhibiting part of a fuse hole, were also found. other artifacts include metal and bone buttons, square nails and other objects of metal, fragments of bottle and window glass, and a variety of pottery sherds. These and other objects collected will be discussed in more detail in the chapter on artifacts.

Also during excavations, traces of what appears to have been the edge of a second palisade trench were uncovered in Units 7 and 12 (Fig. 3). The remnant of this second probable trench is located $1.90 \mathrm{~m}(6 \mathrm{ft}$.) south of the first trench, extending parallel with it, and is of the same orientation.

The temporary fortification installed here, probably in preparation for battle, is described as consisting of two rows of cedar piles six feet apart, with the space between filled with earth from a ditch dug in front (Chabot 1941:24).

\section{The Alamo Shrine Foundation}

Excavations against the building wall exposed sections of the foundation which provided a view of the construction and its condition. The foundation wall which supports the large church structure is nearly four feet in width and is very sturdy. The foundation, at least in our limited tests, was found to be dry and in excellent condition, and is the reason the building stands firm today.

The base of the church wall, which rests upon the foundation, is $24 \mathrm{~cm}$ below the present flagstone paved surface. At this level, there appears to have been older flagstone paving possibly dating to the mission period. Some flagstone fragments were found to butt against the wall base. These earlier flagstones were possibly either part of an old walkway extending along the building wall or remnants of church courtyard paving.

The building foundation wall is thicker by several centimeters than the church wa11 it supports, and it extends down $60 \mathrm{~cm}$ to where it rests upon a wall footing of the same thickness. This level is coincidental with the top of the dark brown clay, which evidently was the original construction-period ground surface. The foundation wall is constructed of large, load-bearing irregular stones and slabs which are roughly dressed on the facings and maintain fairly even coursing and alignment (Figs. 8, 9, 10). These stones, which are generally around 10 to $20 \mathrm{~cm}$ in height and roughly 20 to $40 \mathrm{~cm}$ in length, are laid in rough horizontal coursing, using gray to occasionally pink sandlime mortar and many spalls to fill the larger mortar joints and to aid in setting the stones.

The footing upon which the foundation wall rests is not as carefully built, and uses rubble stones and slabs set without coursing in yellowish sandlime mortar. It appears that the footing trench had been dug through the dark brown clay to the underlying base caliche, a depth of more than a meter. Stones and mortar had been placed into the trench to provide the footing. These were not merely dumped into the trench but were carefully set to bear the load. It seems possible that 
the footing had been installed some years prior to the construction of the foundation and might be the footing which supported the original stone church that subsequently collapsed. The construction of the foundation footing is remarkably similar to the technique recorded at Missions San Juan Bautista and San Bernardo (Eaton 1975, 1976).

In building the church, there seem to have been three distinct construction phases: (1) a foundation footing resting upon basal caliche which was placed within a footing trench; (2) a foundation wall installed upon this which rose above the old ground surface; and (3) the church walls, slightly less in thickness, which rest upon the foundation. The building walls above the foundation are described in the chapter on architecture. 


\section{THE ARTIFACTS}

The artifacts collected from excavations in front of Alamo Shrine will be very briefly described. They are presented by material types and are not in chronological order. Also in the collection are non-artifact plant and faunal remains which may be culturally related. A summary of the collected materials and proveniences is presented in Table 1.

Although the collection is not particularly large, it does contain a broad variety of cultural materials which evidently date from the mission period to modern day. Some of the materials, notably certain metal artifacts, are clearly remnants of the famous Battle of the Alamo.

Pottery fragments, which are important cultural and chronological indicators, were collected from each of the soil levels tested. At least 17 different wares have been identified; however, all of the pottery collected are very sma11 rim and body sherds. The fragments are usually large enough to identify the ware, but generally too small to clearly identify original form and use. Many of the wares in the collection are datable since they are known to have been made and were in general use during certain time periods.

Al1 glass specimens in the collection are also very small fragments. These evidently represent window and bottle glass, but form identification is not possible. Although bottle form, color, and manufacturing technique are diagnostic characteristics regarding dating and use, the small fragments in the collection provide little more than color character.

Some Edwards chert was recovered from the excavations. Most is in the form of chunks and flakes, and there is one core fragment. Certain larger flakes are retouched and were evidently used as tools. Also in the collection are two "mission type" (Guerrero) arrow points (Hester 1977, Fox 1979) and a point preform, and two probable gun flint fragments. Most of the worked chert was probably from mission Indian-made artifacts.

The artifact collection includes a relatively large amount of metal objects. Some are quite distinct and identifiable regarding period and use, while others have uncertain identity; there are also many unidentified metal scraps. The most numerous objects found were square iron nails, and these were found in differing sizes. The excavation of the palisade ditch produced a variety of military artifacts from the 1836 battle.

Bone artifacts were few in the collection and included a button, a cuff link, and a tubular bead. The button and link were associated with the battle artifacts, but the bead was probably mission Indian.

Some building materials were collected from the excavations. Included are fragments of ceramic tile, brick, flagstone, mortar, and plaster. The small mortar specimens are samples from the building foundation and footing walls.

Also in the collection are specimens of charcoal, hackberry seed, snail and mussel she11, and animal bone. Animal bone, evidently kitchen refuse, was very plentiful in all excavations. Bone material will be described in the chapter on faunal remains. 


\section{Artifact Proveniences \\ Alamo Shrine (41BX6)}

Soit Type

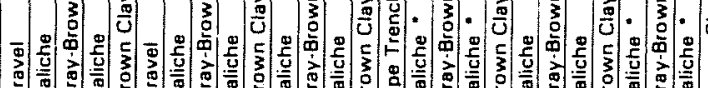

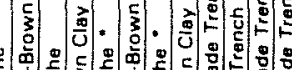

Artifacts

它

\begin{tabular}{|c|c|c|c|c|c|c|c|c|c|c|c|c|c|c|c|c|c|c|c|c|c|c|c|c|c|}
\hline & Arrifacts & Unit-Level $\leq$ & 4 & -1 & $\underline{-}$ & ISI & 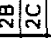 & 只岗 & ज्ञा & 恕 & |्ला & m & 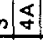 & $\log$ & 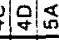 & 国思 & 它 & & 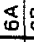 & 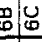 & 要 & & 里i & 지용 & $\$$ \\
\hline & Majolica, Aranama Polychrome & & & & & & & & & & & & & & & & & & & & & & & & \\
\hline & Majolica, Guanajuato Polychrome & & & & & & & & & & & & & & & & & & & & & & & & \\
\hline & Majolica, Puebla Blue on White & 1 & 1 & & & & & & & & & 1 & 1 & & 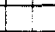 & & & & & & & & 1 & & \\
\hline & Majolica, Puebla Polychrome & & & & & & & & & & & & & & 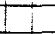 & & & & & & & & & & \\
\hline & Majolica. Puebla Plain & & & & & & & & & & & & 1 & & & 1 & & & & & & & & & \\
\hline & Goliad & & & & & & & 2 & & & 1 & $\begin{array}{ll}12 \\
\end{array}$ & 2 & 1 & 9 & & & 1 & 1 & & 1 & & & 1 & \\
\hline & Mocha & & & & & & & & & & & & 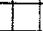 & & 1 & 1 & & & & & 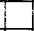 & & & & \\
\hline & Peariware & 2 & 2 & & & & & & & & & & 2 & & & & & & 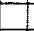 & & 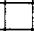 & & & & 1 \\
\hline$\overline{\bar{J}}$ & Polychrome Lead Glaze & & & & & & & & & & & & & & & & & & 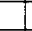 & & 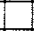 & & & & 2 \\
\hline 5 & Sandy Paste Lead Glaze & & & & & 1 & & & & & & & & & & & & & & & + & & & & $\square$ \\
\hline & Brown Slip Ware & & & & & & & & & & & & & & & & 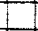 & & 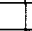 & & 7 & & & & 2 \\
\hline & Tanalá & 1 & & & & & & & & & & & 1 & 1 & 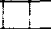 & & & & 1 & & 1 & & & 1 & \\
\hline & Ironstone & & & & & & & & & & & & & & 1 & 1 & & & & & & & & & 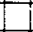 \\
\hline & Unslipped Utility, Plain & & 5 & & & 2 & 21 & & 9 & 2 & 1 & 1 & 12 & 1 & 7 & 1 & 8 & & 2 & 2 & & 5 & 5 & & 5 \\
\hline & Unslipped Utility, Red Paint & 1 & 1 & & & & & & & & & & 1 & & 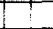 & 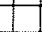 & & & & 1 & & 1 & & & \\
\hline & Porcelain, Oriental & & & & & & & & -1 & & & & & 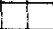 & 1 & I & & & & & & & & & \\
\hline & Glazed Animal Figure & & & & & & & & 1 & $\pi$ & & & & & & & & & & & & & & & \\
\hline & Creamware & & & & & & & & & & & & & & & & & & & & & & & & \\
\hline & & & & & & & & & & & & & & & & & & & & & & & & & \\
\hline & & & & & & & & & & & & & & & & & & & & & & & & & \\
\hline & Clear, Flat & 12 & & & & 2 & & & 1 & & & & 1 & 1 & 11 & 1 & & & 1 & & & & 5 & 1 & 3 \\
\hline & Clear, Bottle & & & & & & & & & & & & (4 & & & & & & 1 & & & 1 & & & 1 \\
\hline 8 & Green, Bottle & & & $\cdot$ & & & & & & & & & 3 & 1 & & & & & & & & & & 2 & 1 \\
\hline है & Brown, Bottle & & & & & & & & & & & & & & & & & & & & & - & & & 1 \\
\hline & Amber, Bottle & & & & & & & & & & & & & & & & & & & & & + & & & 1 \\
\hline & Light Bive, Bottle & & & & & & & & & & & & & & & & & & & & & & & & \\
\hline & & & & & & & & & & & & & 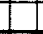 & 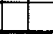 & 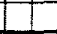 & 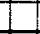 & & & & & . & d & & & 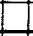 \\
\hline & & & & & & & & & & & & & & & & & & & & & 7 & 1 & & & \\
\hline & Chunks & & & & 2 & & & 2 & \begin{tabular}{|l|l|}
2 & 2 \\
\end{tabular} & & & & 1 & & 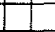 & 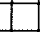 & & 1 & & & 1 & & & 1 & \\
\hline & Flakes & 4 & 2 & & & & 1 & 1 & 11 & 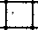 & & 1 & & 1 & 4 & $\square$ & & 1 & & 1 & 2 & 2 & 1 & 3 & \\
\hline$z$ & Core Fragment & & & & & & & & & & & & & & & & & & & & 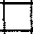 & 1 & & & 1 \\
\hline & Points, Mission Type & & & & & & & & & & & & & & & & & & & & 1 & & & & 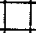 \\
\hline & Gun Fint Fragment & & & & & & & & & & & & & 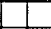 & & & & & & & & & & & 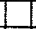 \\
\hline & & & & & & & & & & & & & & & & & & & & & & & & & 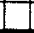 \\
\hline & & & & & & & & & & & & & & & & & & & & & & & & & 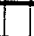 \\
\hline & Fragments, Iran & 6 & & & & \begin{tabular}{|l|l|}
2 & 1 \\
\end{tabular} & & & 1 & & & 1 & & 1 & 2 & 21 & & & 1 & & & & & & 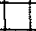 \\
\hline & Fragments, Lead & & & & & & & & & & & & & & & & 1 & & 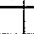 & & & & & & - \\
\hline & Nails, Square & 22 & & & & \begin{tabular}{|l|l|}
6 & 14 \\
\end{tabular} & & & 10 & & & & 3 & 1 & 126 & 6.1 & & & 2 & & & 1 & & & 12 \\
\hline & Tacks, Round & 1 & & & & & & & 1 & & & & & 1 & 1 & 1 & & & & & 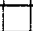 & & & & \\
\hline & Tacks, Square & & & & & & & & 1 & & & & 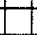 & 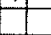 & & & & & & & 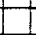 & 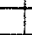 & & & 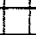 \\
\hline & Strap, Iron & & & & & 1 & 7 & & & & $\%$ & & 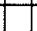 & - & - & 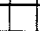 & 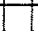 & & & & 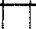 & - & & & 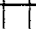 \\
\hline & Brackat, Iron & & & & & & & & $\rightarrow$ & & & & 1 & 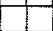 & . & + & & & & & + & & & & 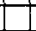 \\
\hline & Machine Screw & & & & & & & & $\rightarrow$ & & & & 1 & & & + & & & & & + & & & & 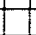 \\
\hline $\bar{E}$ & Cartridge, Brass & & & & & . & & & 1 & & & & & 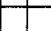 & & $\rightarrow$ & & & & & 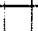 & & & & 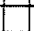 \\
\hline$\frac{9}{2}$ & Button, Brass & & & & & & & & & & & & & & & & & & & & 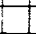 & & & & \\
\hline & Buckle, Brass & & & & & & & & & & & & & & & & & & & & & & & & \\
\hline & Musket Sting Swivel & & & & & & & & & & & & 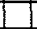 & E & & & & & & & & & & & $\rightarrow$ \\
\hline & Balls, Lead & & & & & & & & & & & & & & & & & & & & & & & & 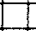 \\
\hline & Balls, Brass & & & & & & & & & & & & 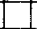 & 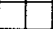 & & & & & & & & 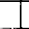 & & & \\
\hline & Spherical Shells. Bronze & & & & & & & & & & & & & & & & & & & & & 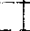 & & & 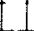 \\
\hline & Special Tool & & & & & & & & & & & & & 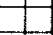 & & & & & - & 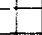 & & - & & & \\
\hline & U-Handle, Iron & & & & & & & & & & & & & & & & & & 1 & & & & & & \\
\hline & & & & & & & & & t & & & & & 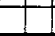 & & 1 & 1 & & & & & & & & \\
\hline & & & & & & & & & & & & & & & & & & & & & & & & & \\
\hline & Button & & & & & & & & & & & & & 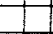 & & & & & & $t$ & & & & & 7 \\
\hline 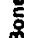 & Cuff Link & & & & & & & & & & & & & & & & & & & & & & & & \\
\hline & Tubular Bead & & & & & & & & & & & & & 1 & & & & & & & & & & & \\
\hline & & & & & & & & & & & & & & 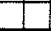 & & & & & & & & & & & \\
\hline 类 & & & & & & & & & & & & & & & & & & & & & & & & & \\
\hline$\frac{9}{6}$ & Tile. Red Ceramic & & & & & \begin{tabular}{|l|l|}
4 & \\
\end{tabular} & & & 4 & & & & 2 & & & & & & 1 & & & & & & 1 \\
\hline 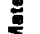 & Brick, Red Ceramic & & 2 & & & 1 & & & & & & & & & & & & & & & & & & & \\
\hline 5 & Mortar, Samples from Foundetion & & & & & & & 1 & & & & & & 1 & & & & & & & 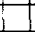 & & & & \\
\hline$\underline{E}$ & Plaster & 1 & & & & & & & & & & & & & & & & & & & & & & & \\
\hline 혹 & Flagstone Fragments & & 1 & & & & & & & & & & & & & & 1 & & & & & & & & \\
\hline జ & & & & & & & & & & & & & & & & & & & & & & & & & \\
\hline & & & & & & & & & & & & & & & & & & & & & & & & & \\
\hline & Charcoal & $\mathrm{x}$ & & & & & & & & & & & & & & & & & & & & & 1 & & \\
\hline$\dot{0}$ & Seed, Hackberry & & & & & & & & & & & 1 & & & & & & & & & & & & & \\
\hline$\frac{9}{2}$ & Land Snail Shells & & & & 4 & & & 70 & & & & & & 1 & & & & & & & 1 & & & 97 & \\
\hline & Muesel Shells & 1 & & & & & & \begin{tabular}{l|l}
1 & \\
\end{tabular} & & & & & & 1 & & & & & & & 1 & 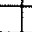 & 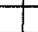 & 1 & \\
\hline & Animal Bone & 0 & 0 & 0 & 0 & 00 & 10 & 0 & 10 & ol & 11 & 0 & o & 0 & 10 & 0 & 0 & 5 & 0 & 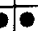 & - & 0 & 0 & $\sqrt{0}$ & - \\
\hline & & & & & & -1 & & & & & & & & & & & & & & & & & & & \\
\hline
\end{tabular}




\section{CERAMICS}

The pottery wares described below were identified by Anne Fox, who also provided some basic chronological information. Perhaps a variety of forms, such as plates, cups, etc., are represented; however, since the collection consists entirely of small sherds, form identity was not attempted.

Guanajuato Polychrome majolica (1 specimen)

Tin-enameled earthenware with fine-textured red paste. The paste is much darker than most other majolicas. The specimen has polychrome design on white. The colors include light and dark brown, and green (Fig. 12,a). This is Spanish Colonial ware of the early 1800s.

Puebla Blue-on-White majolica (9 specimens)

Tin-enameled ware with pinkish tan paste. Blue floral design on white (Fig. 12,b,c). Although blue-on-white majolica wares are still made in Puebla, Mexico, this specimen is a ware which was made during 1700-1850.

Puebla Polychrome majolica (4 specimens)

Tin-enameled ware with light pink to tan fine paste. Polychrome design on white with colors including light brown, blue, and yellow (Fig. 12,d). This is a Spanish Colonial ware which was not made after 1725 and is rarely seen in San Antonio mission collections.

\section{Aranama Polychrome majolica (1 specimen)}

Tin-enameled ware with pink paste of generally fine texture but with occasional small inclusions. Polychrome design on white. Colors on specimen include orange-brown and green (Fig. $12, e$ ). This is a Spanish Colonial Mexican ware made during 1750-1850.

\section{Puebla Plain majolica (1 specimen)}

Tin-enameled ware with pinkish tan paste. This small fragment could actually be either plain or blue-on-white majolica since no color is present.

\section{Goliad (19 specimens)}

This ware has a light to medium brown low gloss surface inside and outside; however, irregular firing of the pottery frequently produces zones of gray to black. The paste generally fires gray to black due to bone tempering materials (Fig. $12, f)$. 
The pottery is found at Spanish missions in Texas and was evidently an Indianmade ware of local manufacture. It has been suggested that this ware may have descended from earlier Leon Plain bone-tempered ware (Campbe11 1962:335).

Mocha Polychrome (6 specimens)

A hard paste earthenware with polychrome designs on white. The small specimens in the collection have colors that include black, blue, brown, yellow, and gray. The wares have a fine white paste and high gloss glaze (Fig. 12,g-i). This is an English-made ware produced during the early to middle 1800s.

\section{Pearlware (25 specimens)}

This earthenware pottery has fine hard white paste and high gloss glaze and comes in a wide variety of forms, colors, and decorative schemes. It is an English ware and dates generally to the Anglo period between 1820 and 1855. In the collection are small sherds of banded pearlware (Fig. 12,0), blue shell-edged pearlware (Fig. 12,j), blue-painted pearlware (Fig. 12, m), hand-painted pearlware (Fig. 12,1 $n$ ), transfer-painted pearlware (Fig. 12,p-q), and plain white pearlware (Fig. 12,k)

\section{Creamware (2 specimens)}

This earthenware is thin walled with fine white paste. It is off-white to cream in color with high gloss glaze. Creamware is a late 18th century English pottery made earlier than pearlware and was probably its forerunner (Fig. 13,a).

\section{Polychrome Lead Glaze (4 specimens).}

This is a Mexican-made earthenware with medium brown glazed interior and exterior with polychrome designs. The paste is pink. This pottery type was made from about 1750 onward, with some similar types still being made.

Sandy Paste Lead Glaze (4 specimens)

Also called Mexican lead-glazed ware. This pottery was made during the 18th and 19th centuries. It is a heavy ware with pink sandy paste. The exterior has a light green glaze (Fig. 13,b).

Brown slip ware (2 specimens)

A utility pottery probably made during the middle to late 19th century or later.

Tonalá (7 specimens)

A thin pottery with medium brown burnished slip inside and outside. It has a gray to $\tan$ fine paste (Fig. 13,C). This ware was made during the mission period and probably also until the middle or late 1800s. 
Ironstone (2 specimens)

Glossy white ware with fine white paste. This was originally made in England from the early 1800s until the present, but also was made locally after the Civil War.

Unglazed Plain Utility Ware (88 specimens)

The paste ranges from buff to pink in color and is often coarse in texture with particle inclusions (Fig. 13,d,e). The dating and manufacture is uncertain, but it appears to have been made during the mission period and for some time afterward.

Unglazed Plain ware Red Paint (5 specimens)

The pottery is very similar to the ware described above and may actually be the same ware, except for a dul1, red-painted exterior (Fig. 13,f,g).

Oriental Porcelain (1 specimen)

This imported pottery, probably coming from the Orient by way of the Manila Galleon, first appears during the mission period and reappears occasionally in later periods. The collected specimen is thin with a hard white paste.

The exterior has blue irregular dots on white (Fig. 13,h).

\section{Glazed Animal Figure (1 specimen)}

Probably Mexican. It has a hard white paste beneath white glaze, with brown spots and also traces of yellow and purple (Fig. 13,i).

\section{GLASS}

All collected specimens are small fragments. Most of the flat, clear glass fragments are window glass, but some could be from the flats of square bottles. The rest of the glass fragments are from a variety of bottle types and colors. Included are clear flat window glass fragments ( 42 specimens), clear bottle fragments ( 4 specimens), green bottle fragments ( 21 specimens), amber bottle fragments ( 7 specimens), and light blue (aqua) bottle fragments ( 2 specimens).

\section{CHERT}

Chunks (13 specimens)

A11 small fragments with no visible evidence of knapping. 


\section{Flakes (21 specimens)}

A11 chipping debris consisting of flakes from different stages in the knapping process. Included are primary and secondary thinning flakes and interior flakes, some of which are trimmed and utilized. There is also a large cortex flake end scraper and a secondary flake side scraper (Fig. 14,a,b).

Core ( 1 specimen)

Only one core fragment was collected.

\section{Points ( 3 specimens)}

Three arrow points were collected. These are types characterized as "mission points" since they are found at Spanish Colonial missions in south Texas and northern Coahuila (Hester 1977; Fox 1979). Hester (1977) has applied the type name Guerrero to these points. There are two forms represented in the collection. One of the points has a deeply notched base, while the other two have slightly concave bases. One specimen is a basal fragment of an unfinished point, apparently broken during knapping (Fig. 13,c-e).

\section{Gun Flint (2 specimens)}

Two small fragments of what appear to be gun flints of local chert used in a flintlock musket or pistol.

METAL

The collection includes objects of iron, lead, brass, and bronze. The iron specimens are very corroded and often difficult to identify.

\section{Iron Fragments (34 specimens)}

These include corroded metal scraps and fragments of unidentified objects.

\section{Lead Fragments (2 specimens)}

Included are fragments and sprue. Possibly these are residue from shattered lead balls and from bullet molding.

\section{Square Nails (120 specimens)}

Whole nails and fragments of nails of various sizes (Fiq. 15, h-m). They range from around $2 \mathrm{~cm}$ long to spikes of 6 to $7 \mathrm{~cm}$ long and were used in a variety of constructions. Square nails were made and used from the mission period until the late 19th century. Earlier nails were hand wrought, but later they were cut from stock. 
Round Tacks (4 specimens)

Round head and body cross-section.

Square Tacks (3 specimens)

Square head and body cross-section (Fig. 15,n).

Iron Strap (1 specimen)

Possibly from a wagon or gun carriage (Fig. $15, \mathrm{~b}$ ).

Cartridge (1 specimen)

Brass casing, centerfire, either .44 or .45 caliber (Fig. 15,e).

Machine Screw (1 specimen)

Iron screw, corroded, thread size undetermined.

Brass Button ( 1 specimen)

Sma11 uniform button, plain (Fig. 15,d).

Brass Buckle (1 specimen)

Fragment of a belt or shoe buckle.

Sling Swivel (1 specimen)

Iron bracket for attaching a sling to a Brown Bess flintlock musket (Fig. 15, c).

Special Tool (1 specimen)

An iron tool with a screwdriver blade on one end and an attachment hole on the opposite end (Fig. 15,f). Possibly this tool was attached to a gun carriage as part of the kit (Sam Nesmith, personal communication).

U-Handle (1 specimen)

A U-shaped iron object which appears to have been a handle. Use unknown (Fig. 15,a). 
Lead Ball Ammunition (6 specimens)

Solid spherical shot for musket. Two .69 caliber balls weighing 31.2 grams and 31.7 grams, one .70 caliber bal1 weighing 32.7 grams, and a .46 caliber ball weighing 9.7 grams. Two impacted lead balls, probably .69 to .70 caliber, were also found (Fig. 16,d-i).

\section{Bronze Balls (2 specimens)}

One solid shot of cast bronze, slightly flattened, with a deep hole in one side evidently caused by intense heat during firing. It is roughly 1.15 inch $(2.8 \mathrm{~cm})$ in diameter and weighs 56.4 grams. Possibly this is a canister shot from a 6pounder cannon (Fig. 16,C). Also in the collection is a larger solid shot of cast bronze, 1.3 inch $(3.3 \mathrm{~cm})$ in diameter and weighing 147.2 grams. Possibly this is a canister or grape shot from a Mexican 24-pounder (6-inch) howitzer (Fig. 16,b).

\section{Spherical Shells (2 specimens)}

Fragments of two hollow spherical shells were found. Each is cast bronze, and they differ in thickness and estimated original diameter, although they could have been from the same she11. One of the shel1.fragments is 0.5 inch $(1.3 \mathrm{~cm})$ in thickness and weighs 488.5 grams ( $F i g .16, a)$. In measuring the curvature, it is estimated that the original shell was 7.4 inches in diameter and evidently was fired from the Mexican 8-inch howitzer used to bombard the Alamo prior to the final assault. This was either a common shell with hollow interior filled with black powder and fitted with a fuse, or a spherical case or shrapnel shell which contained many lead balls, generally standard .69 caliber musket ball, in addition to the powder charge, and a cut wooden fuse. The shell fragment has part of a fuse hole estimated to have been 13/16-inch $(2 \mathrm{~cm})$ in diameter. Within this hole was placed a tapering cylindrical beechwood fuse with spaced encircling grooves. Each groove represented a 1/2-second burning time. The hollow core of the fuse held potfire, a quick burning gun-powder. The fuse was cut to selected length for desired burning time prior to inserting into the shel1 (Hughes 1969; Manucy 1949; Peterson 1969)

The second shel1 fragment is 1.3 inches $(3.3 \mathrm{~cm}$ ) in thickness and weighs 588.6 grams. Based on the curvature, the original shell was about 7.2 inches in diameter. Because of the small area of curvature on the surface of the two shell fragments used to calculate the original shell diameter, and since these are fragments from exploded shells and therefore likely to be somewhat distorted, it is possible that the fragments are actually from the same shell. The differences in shell fragment thickness may be a result of the custom of the time of casting shells, with thicker wall opposite the fuse in the belief that the shell would land on the heavier side and not smother the fuse (Hughes 1969).

BONE

Button (1 specimen)

Thin disk, 1.47 inches in diameter, with one center hole (Fig. 14,f). Possibly a shirt button. 
Cuf6 Link (1 specimen)

Portion of link, white.

Tubular Bead (1 specimen)

Cut section of a bird bone $3.9 \mathrm{~cm}$ long and 0.6 to $0.8 \mathrm{~cm}$ in diameter (Fig. 14,g).

BUILDING MATERIALS

Ceramic Tile (13 specimens)

Fragments of floor tiles pink to light red in color. Rectangular form $2.5 \mathrm{~cm}$ in thickness (Fig. 13,j). Probably Spanish Colonial in date and possibly made local1y.

Ceramic Brick (3 specimens)

Red brick fragments differing in dimensions and character from the above tile. Probably late 19th to early 20th century.

Mortar (2 specimens)

Samples taken from the mortar joints of the structure foundation. Sandy lime mortar, light gray in color, with inclusions of small pebbles, limestone spal1, and small clods of dark gray clay.

Plaster ( 1 specimen)

White lime plaster, probably from the structure wal1. One fragment has red paint.

Flagstone (2 specimens)

Fragments of flagstone slab, probably from an earlier paving. Possibly Colonial period.

MISCELLANEOUS MATERIALS

Charcoal (12 specimens)

Small fragments were found in some of the levels and were particularly plentiful in the palisade trench.

Hackberry Seed (1 specimen)

Found in unstratified pipe trench backfi11. Provenience unknown. 
Land Snail Shells (117 specimens)

The collection includes three species: Rabdotus sp., Practicolella sp., and Helicina sp.

Mussel Shell (4 specimens)

Fragments of river mussel she11. Probably obtained from nearby San Antonio River or the acequia.

Animal Bone (4000 specimens)

Bones and fragments of bones were recovered from every excavation unit and level. See the following section on faunal analysis. 


\section{FAUNAL ANALYSIS}

A total of over 4000 animal bones and bone fragments, as well as some animal teeth, was recovered from the 1977 excavations at the Alamo Shrine. However, only a small percent of these are identifiable. Faunal material was found in every level of each of the excavation units and represents at least 11 different genera or species of vertebrates from 37 separate proveniences.

Although the faunal material are representative of only a small area in front of the Alamo Shrine, and probably represent only a few of the many species of animals collected during the periods of occupation, they do provide a partial view of subsistence patterns and allow some observations to be made.

Most of the animals were almost certainly food sources. Some are indigenous to the area, al though others were introduced by the Spanish. Goats, cows, burros, and chickens were domestic animals introduced and raised locally.

Catfish and other unidentified fish, as well as slider turtle, were probably caught in the mission acequias and nearby San Antonio River. Whitetail deer, cottontail rabbit, fox squirrel, and possibly bison were hunted in the general area. The packrat was a common scavenger and probably indigenous, whereas the Norway rat very likely arrived as a stowaway in a cargo shipment. There are many unidentified bone fragments in the collection which may represent other animals.

Table 2 lists the faunal remains which were analyzed by Billy Davidson. Indicated are the scientific and common names, as well as whether the animal was juvenile or adult. The approximate size of fish is indicated by weight.

The provenience of the faunal material is indicated in Table 3. 
Unit 1-A (grave1)

Capra sp. (domestic goat)

Neotoma sp. (packrat)

6 unidentified fragments

Unit 1-B (caliche)

\section{Capra sp.}

16 unidentified fragments

Unit 1-C (gray brown soil)

88 unidentified fragments

Unit 1-D (caliche)

1 unidentified fragment

Unit 1-E (brown clay)

bovid (cow or bison) unidentified rodent unidentified fish

48 unidentified fragments

Unit 2-B (caliche)

Capra sp.

150 unidentified fragments proximal end of humerus

scapula

adult

adult

astragalus

adult phalange

tibia fragment (rat size)

vertebra (large)

2 teeth, astragalus adult

$101 \mathrm{bs}$.

adult 
Unit 2-C (brown gray soil)

17 unidentified bone fragments

Unit 2-D (caliche)

20 unidentified bone fragments

Unit 2-E (black clay)

bovid

unidentified fish

57 unidentified bone fragments

cervical vertebra

vertebra (small individual)

adult

$1 \mathrm{ib}$.

Unit 3-A (caliche)

Sciurus niger (fox squirrel)

101 unidentified bone fragments

Unit 3-B (brown gray soil)

Ictalurus sp.

(blue or channel catfish)

1 unidentified bone fragment

Unit 3-C (caliche)

bovid

10 unidentified bone fragments

Unit 3-D (black clay)

12 unidentified bone fragments incisor

adult

pectoral spine

distal end of ulna

adult 
TABLE 2. (continued)

Unit 3 (intrusive pit)

Equus asinus (burro)

93 unidentified bone fragments

Unit 4-A (caliche)

Pseudemys sp. (slider turtle)

67 unidentified bone fragments

Unit 4-B (brown-gray soil)

66 unidentified bone fragments

Unit 5-A (caliche)

Capra sp.

Unit 5-B (gray brown soil)

\section{bovid}

Capra sp.

6 unidentified bone fragments

Unit 5-C (caliche)

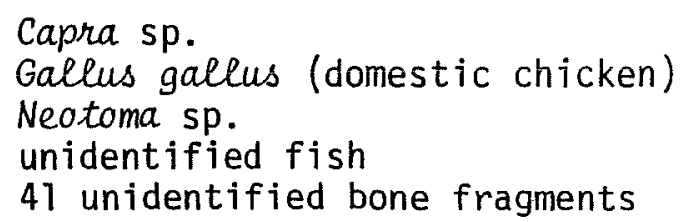

tooth

adult 
Unit 5-D (black clay)

bovid

Capra sp.

67 unidentified bone fragments

Unit 6-A (caliche)

215 unidentified bone fragments

Unit 6-B (brown gray soil)

33 unidentified bone fragments

Unit 6-C (caliche)

29 unidentified bone fragments

Unit 6-D (black clay)

bovid

Capra sp.

Sylvilagus sp.

(cottontail rabbit)

unidentified fish

169 unidentified bone fragments

Unit 7-A (caliche)

23 unidentified bone fragments
2 phalanges

calcaneus

adult

adult

cervical vertebra, tooth fragment,

$$
4 \text { carpals }
$$

4 metapodial fragments

distal end of metatarsal

adult

juvenile adult

vertebra fragment 
TABLE 2. (continued)

Unit 7-B (brown gray soi1)

\section{Pseudemys sp.}

unidentified fish

44 unidentified bone fragments

Unit 7-C (caliche)

49 unidentified bone fragments

Unit 7-D (black clay)

bovid

Capra sp.

Odocoileus virginianus

(whitetail deer)

Neotoma sp.

unidentified fish

560 unidentified bone fragments

Unit 8-A (caliche)

\section{Capra sp.}

Gallus gallus

227 unidentified bone fragments

Unit 8-B (brown gray soil)

Capra sp.

unidentified fish

49 unidentified bone fragments
2 carapace fragments

vertebra

10-20 lbs.
3 phalange fragments, 2 carpals, tooth (at least 2 individuals) carpal

astraga 7 us

metatarsal

vertebra

phalange

coracoid fragment, radius fragment

2 pharanges

vertebra adult and juvenile

adult

adult

adult

$11 \mathrm{~b}$.

adult

adult 
Unit 8-C (caliche)

Capra sp.

unidentified fish

90 unidentified bone fragments

Unit 8-D (black soil)

91 unidentified bone fragments

\section{Unit 9, Pipe Trench}

Neotoma sp.

19 unidentified bone fragments

Unit 10 (Palisade Trench)

Capra sp.

Gallus gallus

Rattus norvegicus (Norway rat) bovid

1,096 unidentified bone fragments

\section{Unit 11 (Palisade Trench)}

Gallus gallus

Capra sp.

394 unidentified bone fragments hoof

skull fragment

adult

$11 \mathrm{~b}$. adult

adult

distal end tibia, calcaneus, distal

fragment of bita, tooth, 2 tooth

fragments, phalange, hoof

phalange

proximal end femur

10 teeth, 3 tooth fragments

( 2 individuals)

adult

adult

radius

phalange adult juvenile 
TABLE 3. FAUNAL SPECIES AND PROVENIENCES, ALAMO SHRINE (41 BX 6).

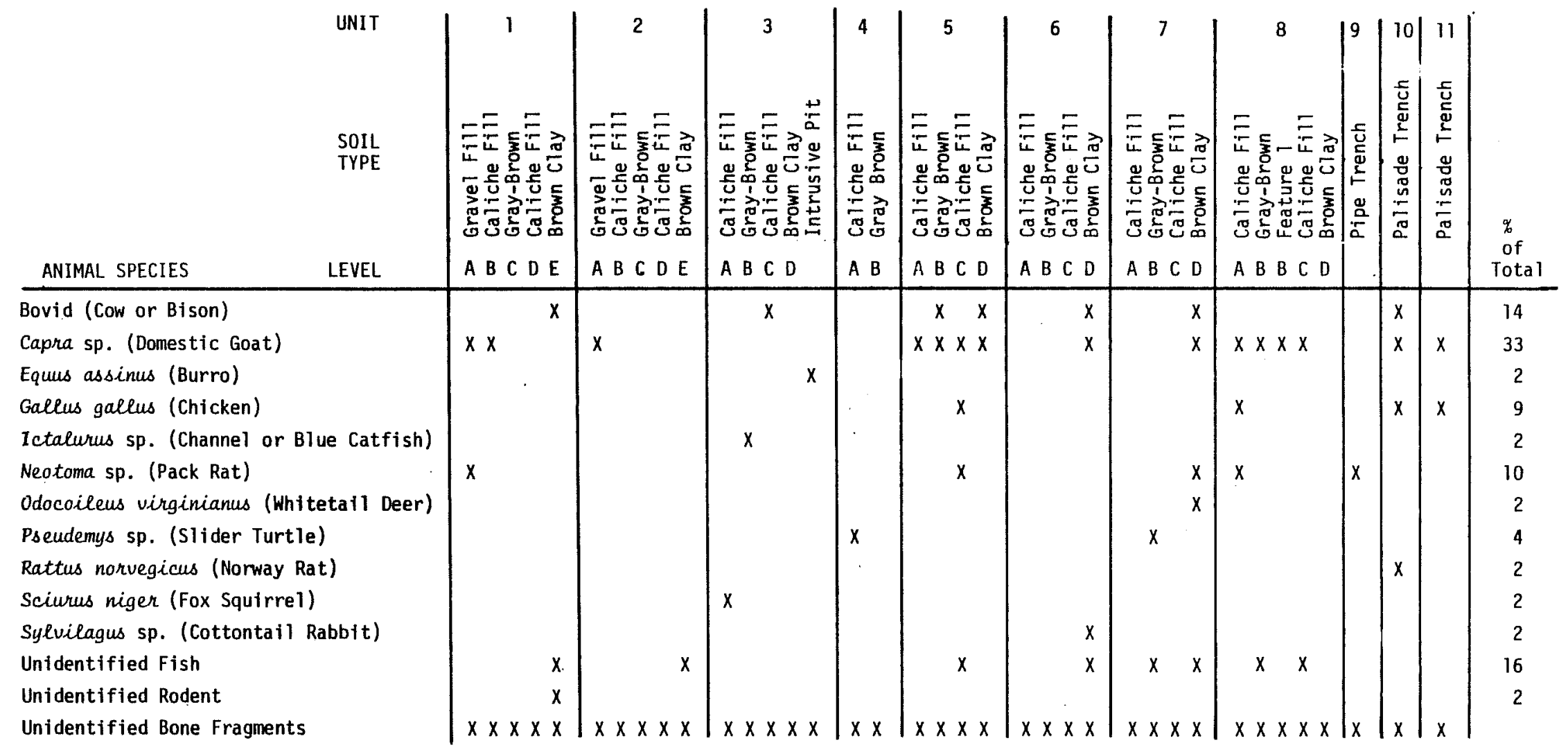




\section{CONCLUDING REMARKS}

The Alamo Shrine, last standing remnant of Mission San Antonio de Valero, was built during the 1740s and 1750s as a mission church which was never completed. The archaeological excavations in front of the Alamo have shown that the structure was built upon the dark clay-like loam of an ancient terrace of the San Antonio River. Prior to the construction and occupation at the mission site, the ground cover was probably grasses and scrub; and there were trees, notably cottonwoods, oaks, cedars, and mulberries, which lined the river.

The earliest cultural materials recovered during excavations in front of the Alamo were found upon, and embedded just beneath, the old ground surface. These materials might date to as early as 1725, when the mission was moved to this location from farther downstream.

The Indian artifacts collected evidently were made by mission neophytes and include mission projectile points in addition to chert flakes and flake tools. Goliad ware, a mission-period Indian-made pottery, was also present. If there had been earlier Indian occupation of the mission site, it has not been clearly identified in any of the past excavations on Alamo grounds.

Also on the old ground surface, and in association with the Indian artifacts, were Spanish materials of the mission period. These include fragments of Puebla Blue-on-white majolica and Tonala pottery. Early construction activity is represented by a few square iron nails.

In addition to the Spanish and Indian artifacts, there was a relatively large amount of animal bones recovered. These include cow, goat, whitetail deer, cottontail rabbit, packrat, unidentified rodent and fish, and many more unidentified bone fragments. Although cows and goats were raised at the mission, the faunal remains indicate that local hunting and fishing supplemented domestic food resources.

The white caliche earth with cultural material inclusions which lay over the old ground surface was probably placed there as fill to provide an improved surface in front of the church. It has also been noted in earlier excavations north of the church in the convento patios (Greer 1967; Schuetz 1973). This fill was laid down during the mission period, probably during general improvements sometime after 1744 when construction of the masonry church was underway.

The artifacts collected from the caliche fill are essentially datable to the mission period, and the increased quantity and variety of materials may reflect growing prosperity. The collection includes fragments of Puebla Polychrome majolica (a luxury at the mission), Goliad ware, and unslipped utility wares. Also recovered were small fragments of window glass, green bottle glass, lead fragments, and animal bones. The bones were those of cow, goat, domestic chicken, unidentified fish, and packrat.

There is a relatively thin layer of gray to brown clayey soil deposited over the caliche fill. It is not clear if this was deliberate additional fill or natural accumulation; the sudden change in soil cover in front of the church might be related to the first church collapse or reconstruction activity which occurred sometime shortly after 1757 . 
The cultural materials collected from this soil level can also be dated to the mission period. Although some of the identified items continued to be made and distributed after the mission period, there were no items in the collection which were identified as having been made only after that period. The collection includes Puebla Blue-on-White majolica, Goliad, Tonalá, and plain utility wares. There are clear window or mirror and green bottle glass fragments, square iron nails, and iron scraps. Also there are small chert flakes (chipping debris) and a tubular bone bead of probable mission Indian use. Animal bone was also present and included cow and goat, slider turtle, channel or blue catfish, and unidentified fish. This reflects continued use of both domestic and wild animal resources.

Covering the gray brown soil was a much thicker layer of white caliche earth fill similar in color and texture to the lower caliche fill. Within this level were inclusions of stones and cultural materials. Because of the variety of materials and mixed cultural identity, the time when this fill was deposited is difficult to place, but appears to relate to the post-mission Spanish, Mexican, and AngloTexan occupation. This is indicated by the artifacts collected, and also by noting that the palisade ditch dug prior to the 1836 battle was intrusive into the caliche fill. It is probable that the fill had been laid during the Spanish cavalry occupation, and prior to 1810, when considerable improvements were made at the Alamo complex. The later period materials were probably admixtures.

The earlier cultural material recovered from this fill were fragments of Guanajuato Polychrome majolica, Blue-on-white majolica, Goliad ware, Tonala ware, Sandy Paste lead-glaze ware, and both plain and red-painted unslipped utility wares. All of these wares were made and in general use as early as the mid-1700s to as late as the early to mid-1800s, and were commonly found at Texas missions. Considering the context in which they were found, they could have continued in use during the Spanish and Mexican, and possibly also the Anglo-Texan, occupations.

Also in the fill were fragments of pearlware, mocha, and ironstone wares. These are English-made wares generally of the early to mid-1800s and were in common use by the Anglo-Texas settlers. Some of these items might have been associated with the Texan occupation of the Alamo in 1835 and in 1836, and possibly later.

The collection also contains an assortment of other items, some of which could have been in use during any one of the above-mentioned occupations. These include square iron nails; iron scraps; fragments of window glass; fragments of brown, green, and amber glass bottles; and fragments of red ceramic brick and tile. There was also a chert core fragment and some chipping debris, evidently of Indian work. Also collected, but from the surface of the caliche fill, were square and round iron tacks, an iron handle, an iron special tool, and a .45 caliber brass cartridge. In addition to the artifacts, there were animal bones representing goat, chicken, slider turtle, fox squirrel, packrat, and much unidentified animal bone fragments.

Covering the caliche fill was a layer of crushed 1 imestone gravel. This was deposited prior to the laying of the flagstone sidewalk in 1880 and was probably a leveling fill between the building and the street curb. 
The collected artifacts which are listed from the gravel in Table 1 were, for the most part, probably more closely associated with the upper surface of the underlying caliche. The pottery includes fragments of Puebla Blue-on-white majolica, Tonalá, Mexican lead-glaze, English pearlware, and red-painted plain ware. There was also window glass, lots of square iron nails, and iron scrap. Perhaps some of the last items were construction debris related to the U.S. Army Quartermaster occupation which terminated in 1897, shortly before the sidewalk was built.

The double palisade wall, which extended between the old church southwest corner and the quadrangle, was described as having been installed by the Texans prior to the 1836 battle. Although this is the generally accepted view, it seems possible that this fortification might in fact have been installed during the occupation by General Cos in 1835, when he had the place put in "fort fashion" and ordered other similar palisade defenses erected at the Alamo complex. The Texans were not trained military engineers, and they had little time and materials to do more than hastily patch up breaches in the walls, rig scaffolding, and mount cannons before the Mexican forces arrived. The procurement of materials and construction of the double palisade, and digging the deep fronting ditch which provided the wall core fill, was a formidable task to undertake on short notice.

It is interesting to note that, contrary to established view, the palisade wall evidently did not butt against the old church wall as usually depicted, but instead there was a space left, easy to defend or block off, but wide enough to allow a person to pass. Perhaps this way was used to allow messengers and others to pass in and out of the fortifications unnoticed. The palisade walls were torn down after the 1836 battle, and the ditches backfilled.

A section of backfilled ditch which once supported the inner row of palisades was discovered and excavated during the current study. The mixed soils of the trench fill contained equally mixed cultural materials, since the ditch had cut through the subsurface stratified soil levels already described. Collected artifacts included materials from all occupation periods, as well as military artifacts from the 1836 battle (see Table 1).

In addition, there was much animal bone, mostly cow, but also goat and chicken, and many unidentified fragments. The many cow bones in the backfilled ditch aid in support of the statement that the Alamo defenders brought numerous cows into the complex for their subsistence during the siege.

The Alamo Shrine, although never completed and subjected to repeated attempts to demolish it, has been standing for well over 200 years. There are no serious structural problems, such as shifting or wall cracking due to faulty construction. The sturdy condition can be attributed largely to setting the foundation on firm footing and doing good stonemasonry, all of this adhering to sound planning. The old mission church, and probably also the convento and certain other mission buildings no longer standing, were constructed by skilled stonemasons with the aid of many laborers. Spanish stonemasons of required skill to undertake the building of monumental works were few on the northern frontier during the mission period, particularly during the earlier years when marauding Indians frequently raided the missions and risks were high. However, Tlaxcaltecans from central Mexico, skilled in stonemasonry through centuries of design and construction of monumental 
stone and plaster buildings, and with knowledge of the Baroque and other Spanish works, were sent to San Antonto de Bejar by viceregal authority to aid in building permanent structures in the newly established town (Crawford 1976). Perhaps Tlaxcaltecan masons were employed at Mission San Antonio de Valero.

The archaeological investigations conducted in front of Alamo Shrine have tested and described the series of natural soll levels upon and within which the famous building was constructed. Testing was also made of the subsequent soil fills which were deposited through time by a series of developments related to known historical events. Also, as part of the investigations, sections of the old church foundation were examined to describe the construction, condition, and depth of footing. The examination revealed that the footing is sound, and the stone and mortar construction is of good quality, with no noticeable deterioration.

Cultural resource management at Alamo Plaza, a National Historic Landmark, is of continuing concern. Therefore, the following comments and recommendations are provided for the protection of this valuable historical resource.

The excavations conducted during this study tested portions of the area in front of Alamo Shrine between the front doorway and the southwest corner, and no more than three meters out from the wall where the old street curb was found. Much of the study area was left undisturbed and, as demonstrated, could contain valuable cultural materials which can be related to historical events. The area north of the building front doorway has evidently not been disturbed in the recent past and could contain equally important remnants of past material culture. In addition, the area just south of the current study zone would be the location of the large ditch described to have been dug just outside of the palisade defenses. It was backfilled after the final battle and, if it has not been severely disturbed by the old storm channel in that area, would also be a valuable depository of cultural remains. These areas are referred to in the Alamo Master Plan (Ford, Powe11, and Carson 1979).

We recommend that these areas be protected. Furthermore, should any disturbance be planned in the course of future developments on Alamo grounds which could affect those areas, a qualified archaeologist should be consulted. 


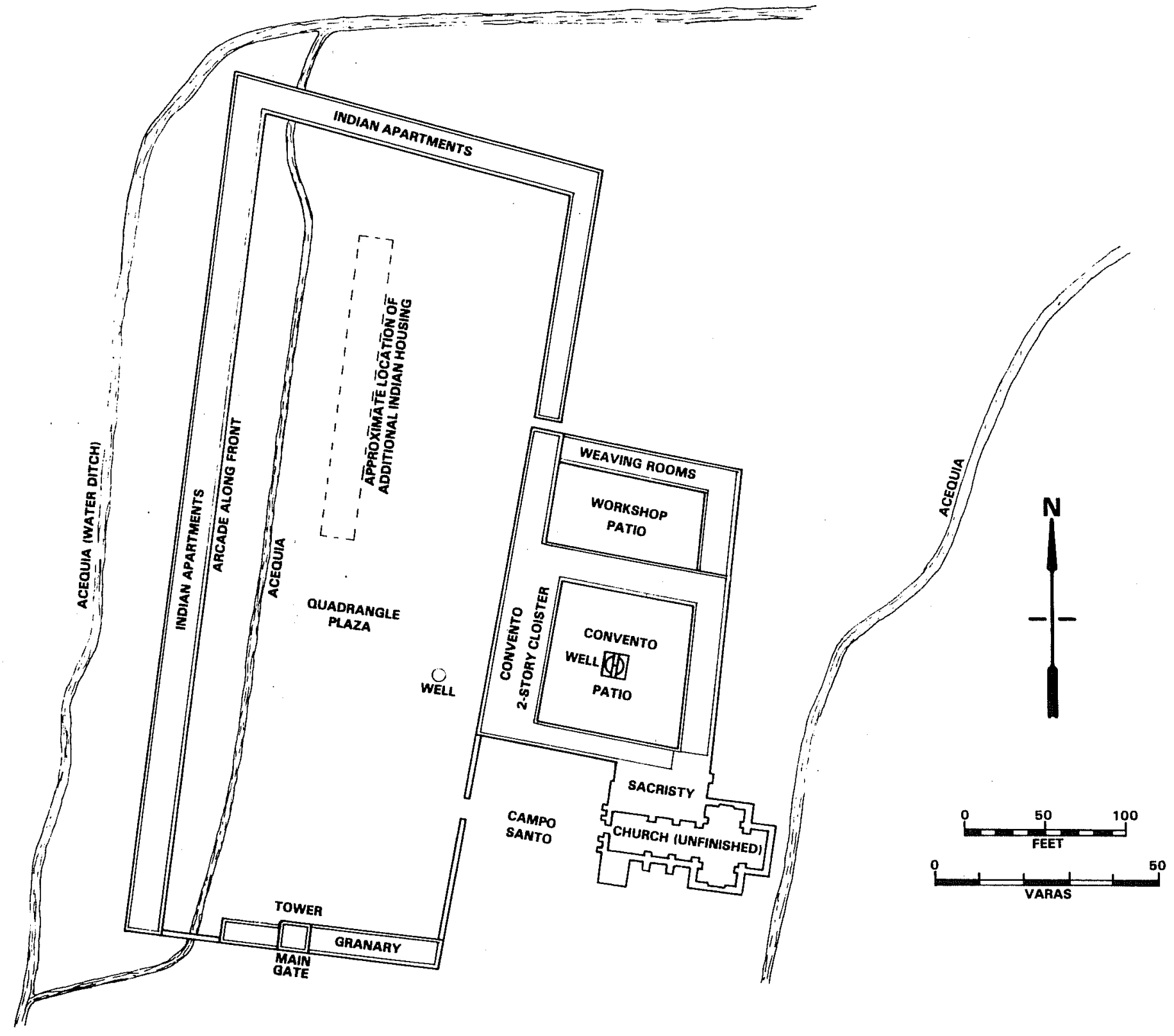

Figure 1. Mission San Antonio de Valero. Plan of the mission complex as it probably looked in the 1760s. 


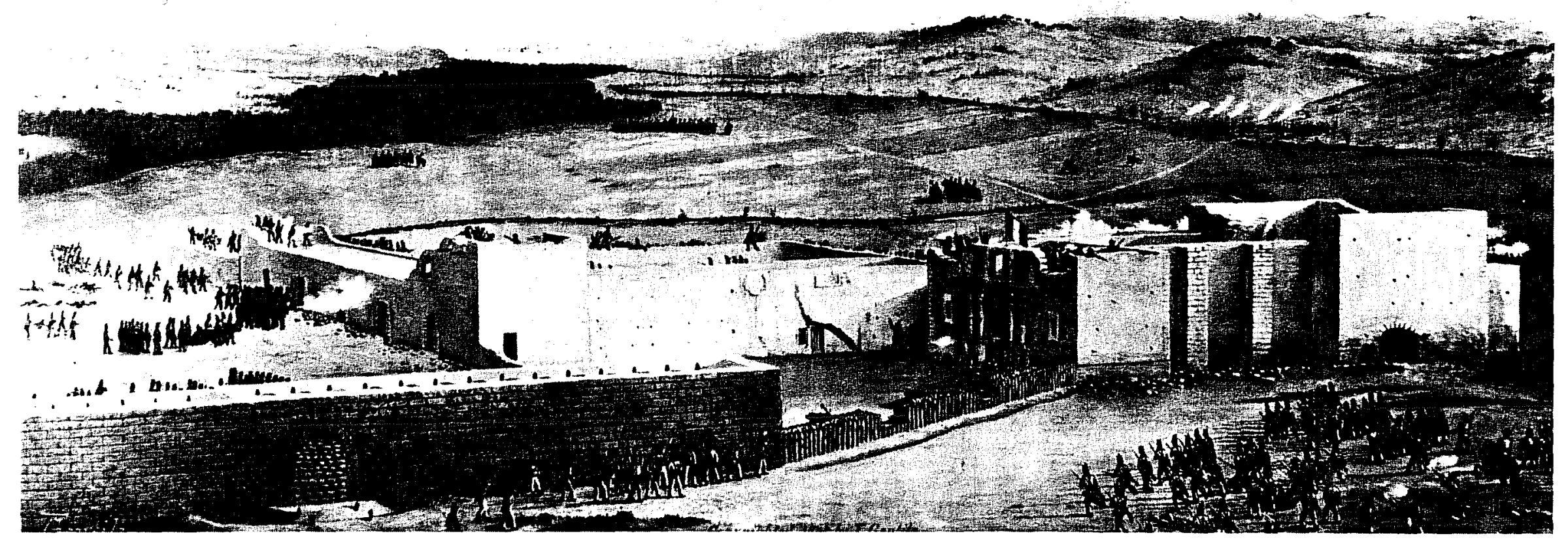

Figure 2. Battle of the Alamo. The final assault on the Alamo in the early morning of March 6 , 1836. The scene is depicted by Theodore Gentilz, a French artist, in 1844. Photograph courtesty of Mr. Charles Long and the Daughters of the Republic of Texas. 


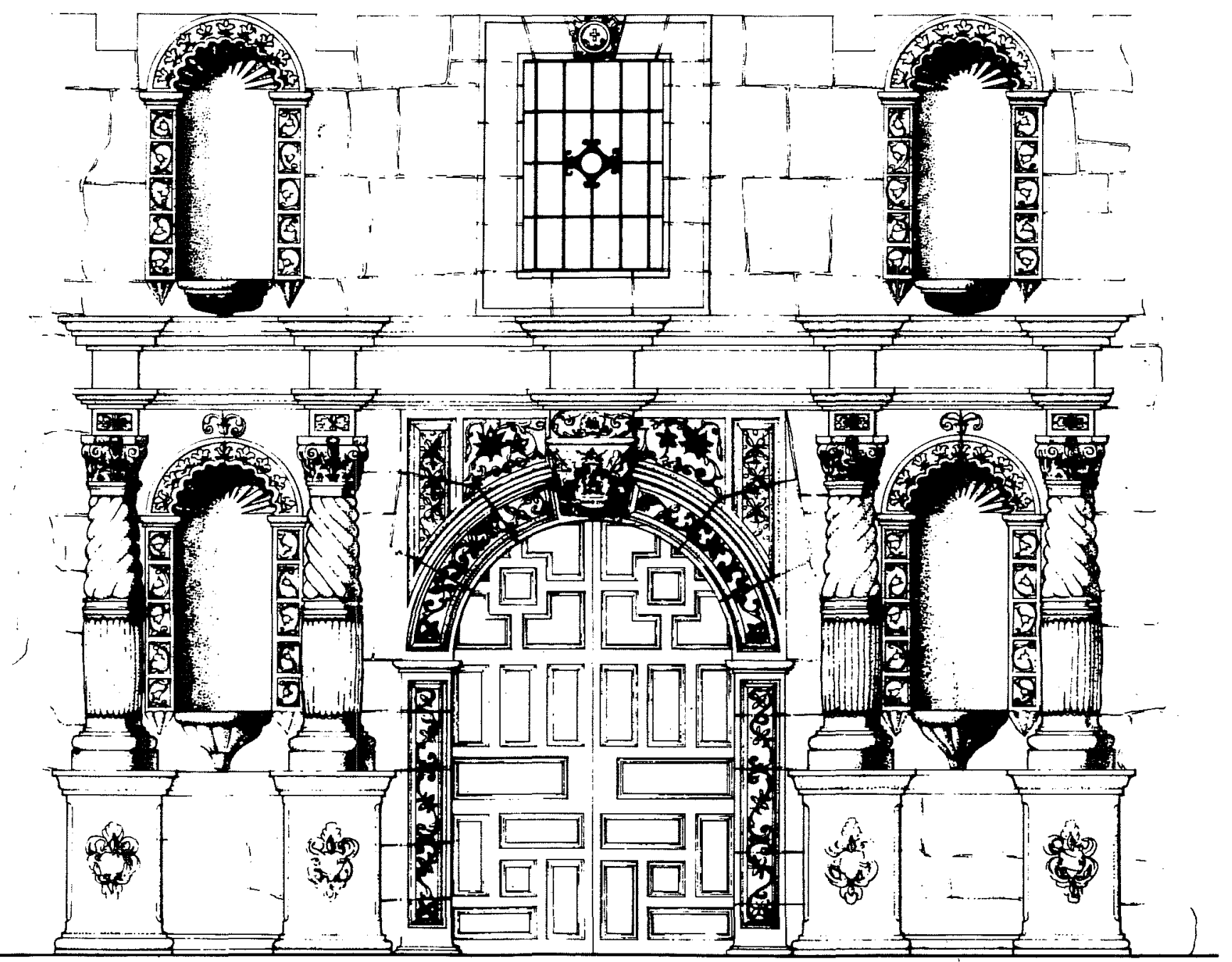

Figure 4. Alamo Shrine Facade. An elevation view of the current facade. This is the lower portion of a planned larger church facade never completed. Courtesy of Eugene George, AIA Architect and the Texas Historical Commission. 


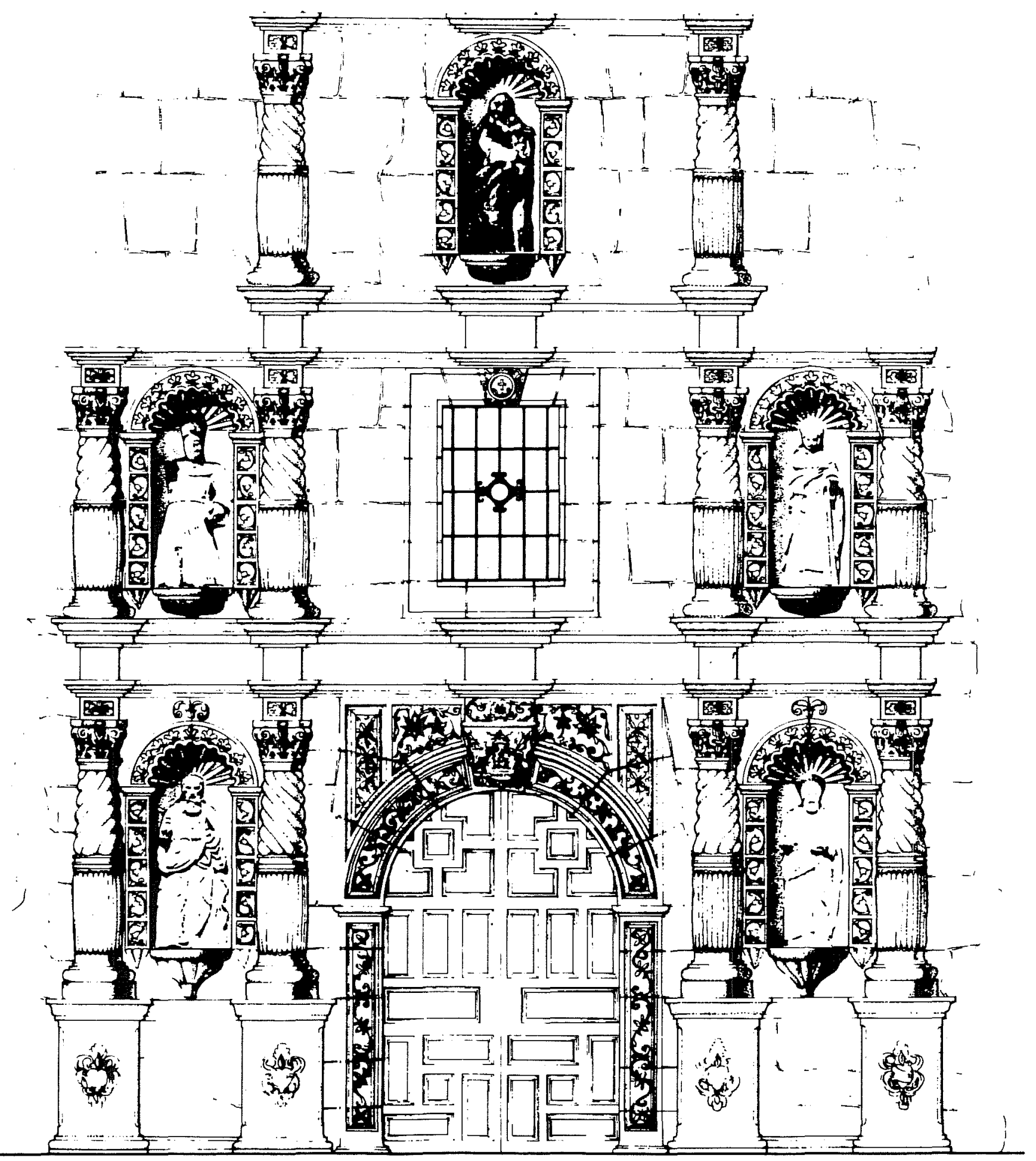

Figure 5. San Antonio de Valero Mission Church Facade. A reconstruction of the planned (but not completed) design as described in 1772 inventory. A 17th century Early Baroque retable facade. 


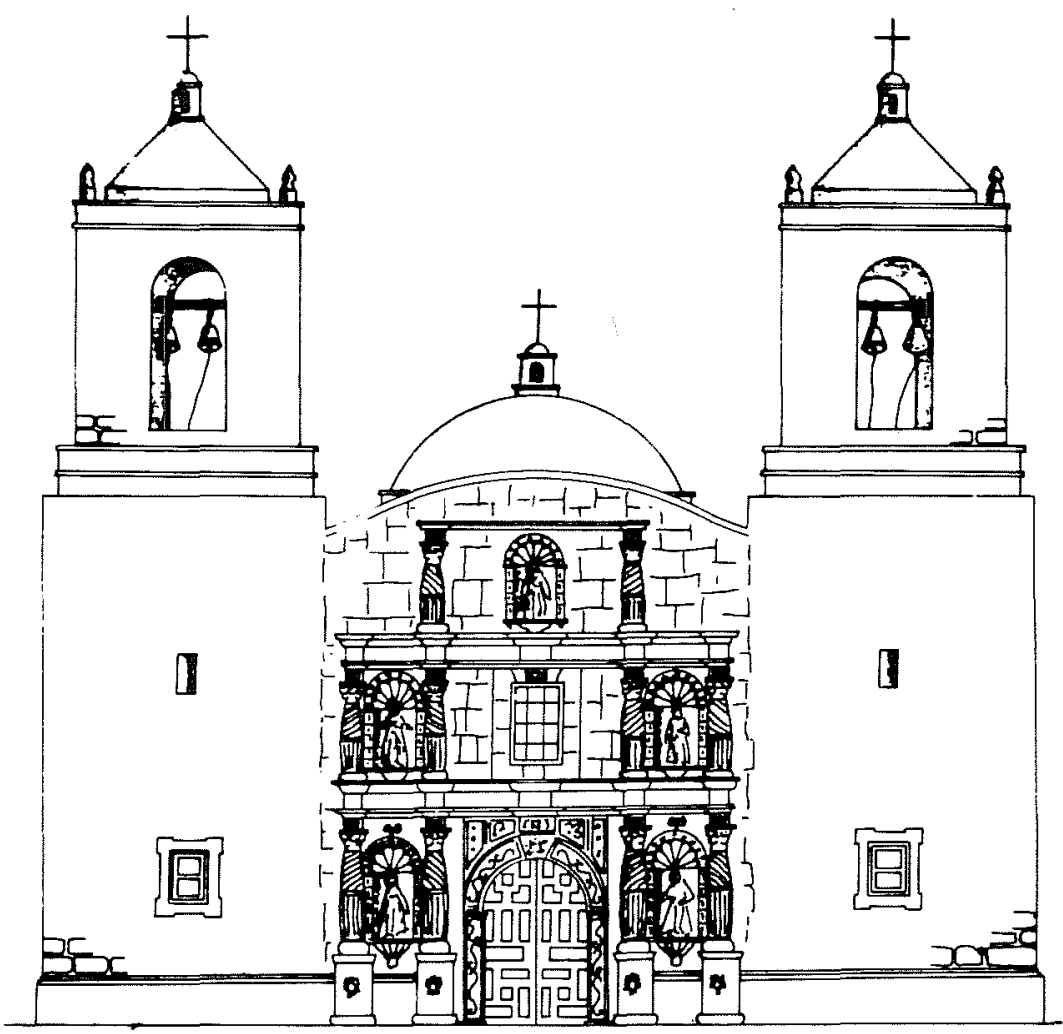

2.
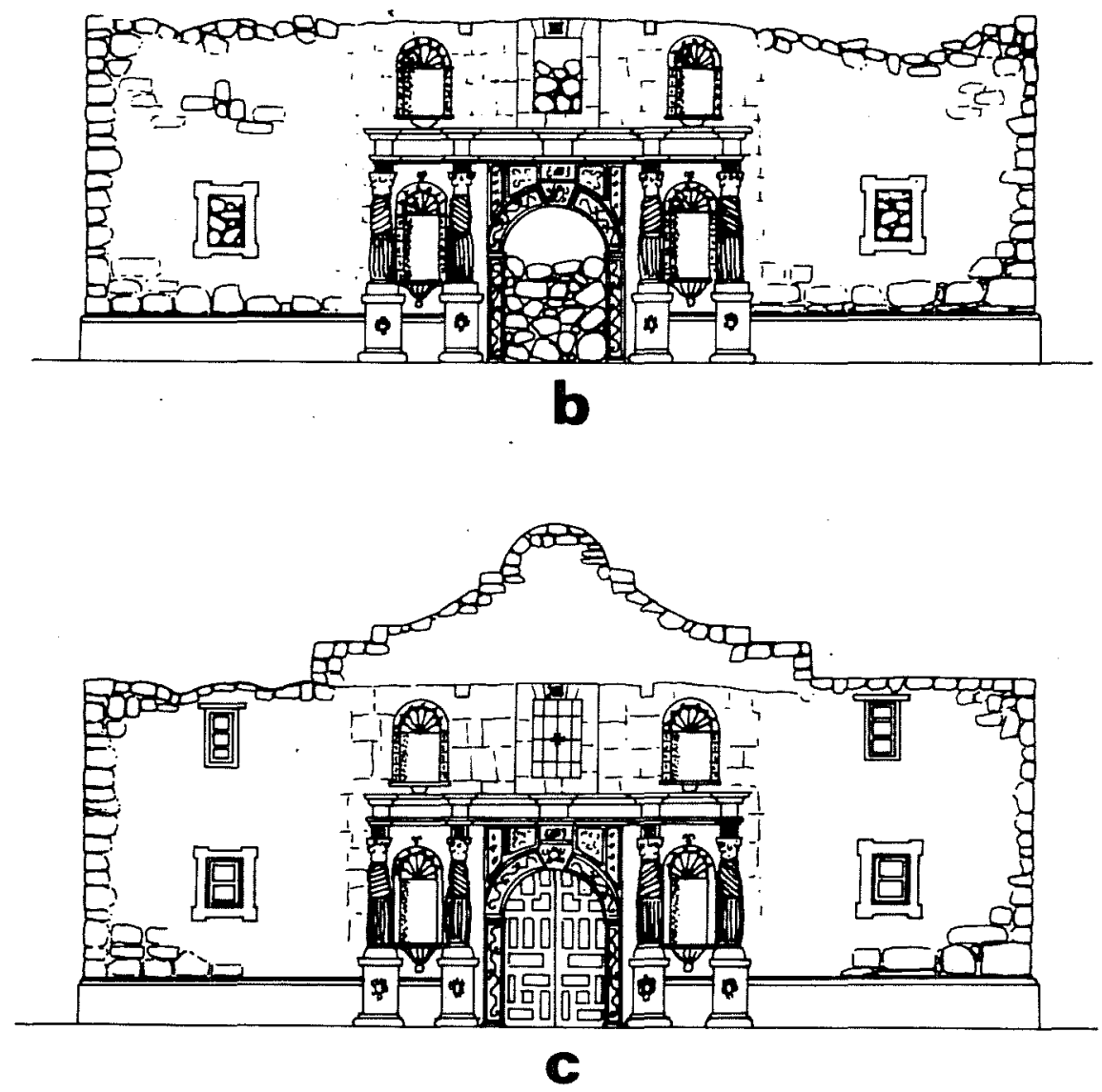

Figure 6. San Antonio de Valero Mission Church (The Alamo). a, suggested original elevation view of mission church, planned but not completed; $b$, the Alamo at the time of the 1836 battle; $c$, the Alamo as seen today, with added gable and upper wíndows. 


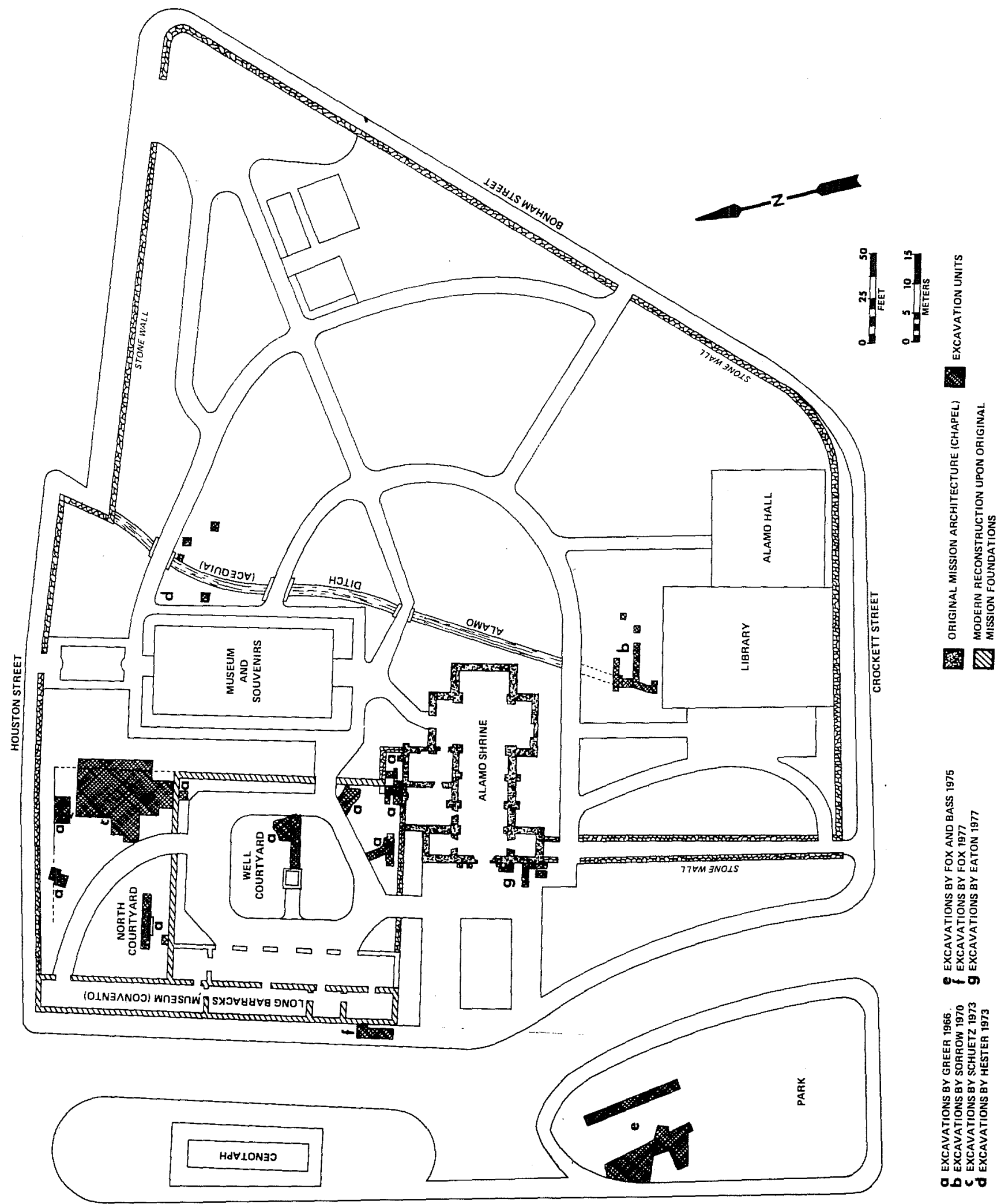

Figure 7. Alamo Grounds. Shown are locations of past archaeological excavations. Basic plan of grounds courtesy of Mr. Charles Long and the Daughters of the Republic of Texas. 


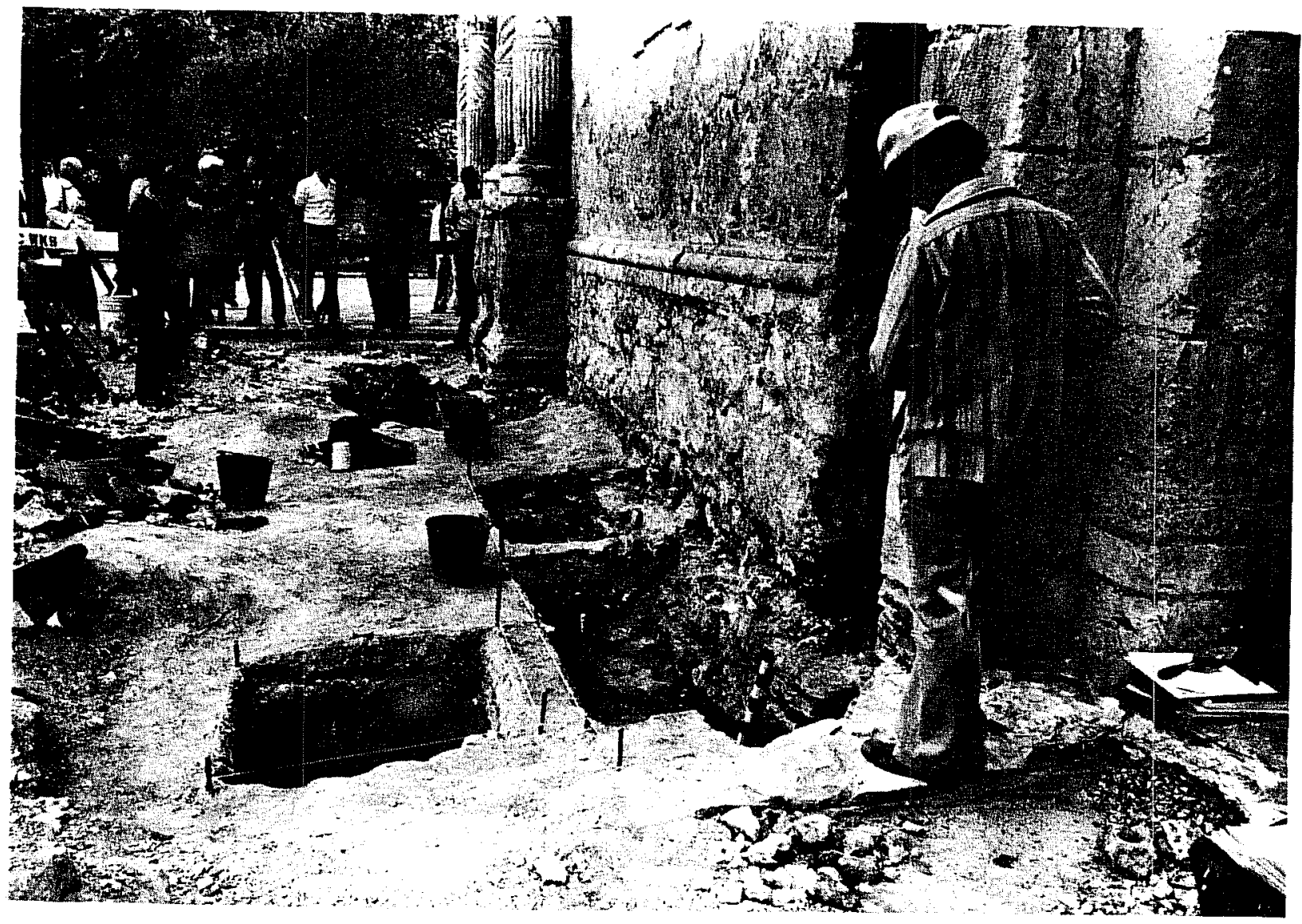

a

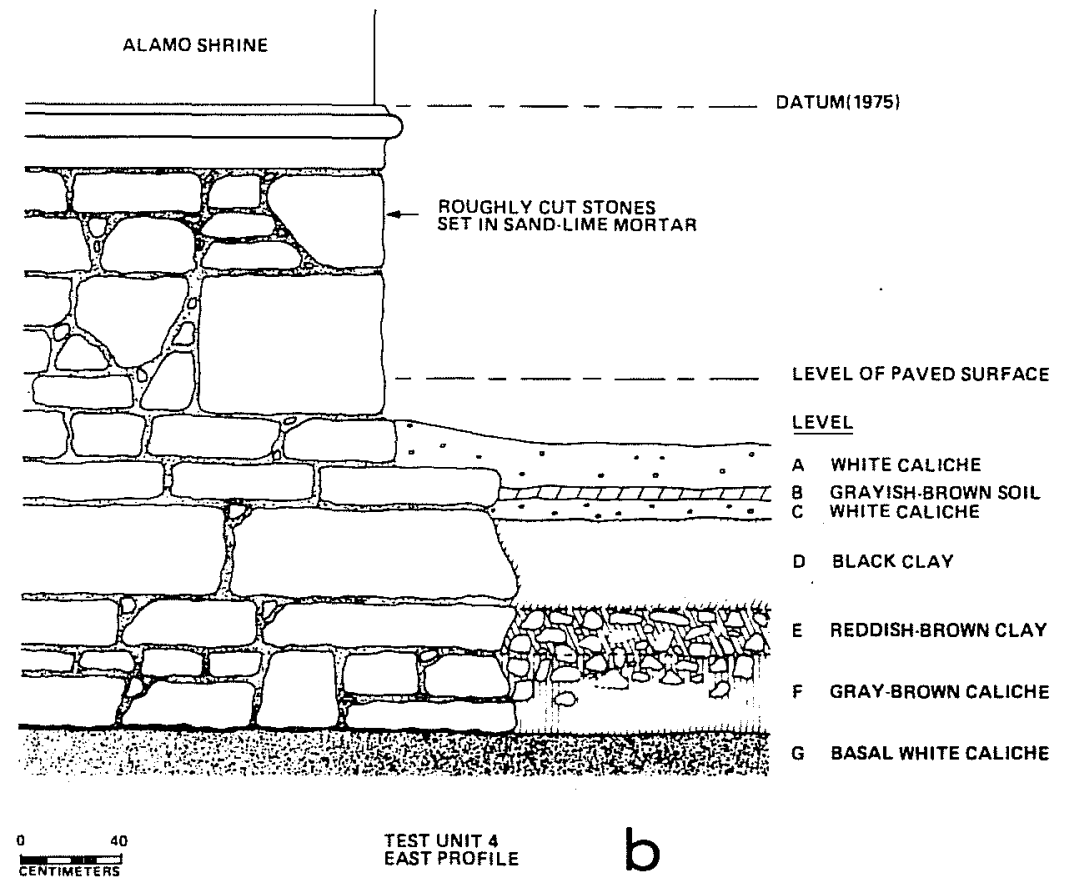

Figure 8. Excavations in Front of Alamo Shrine. a, view of initial excavation units, looking north; $b$, elevation of building's southwest corner and basic soil profile. 

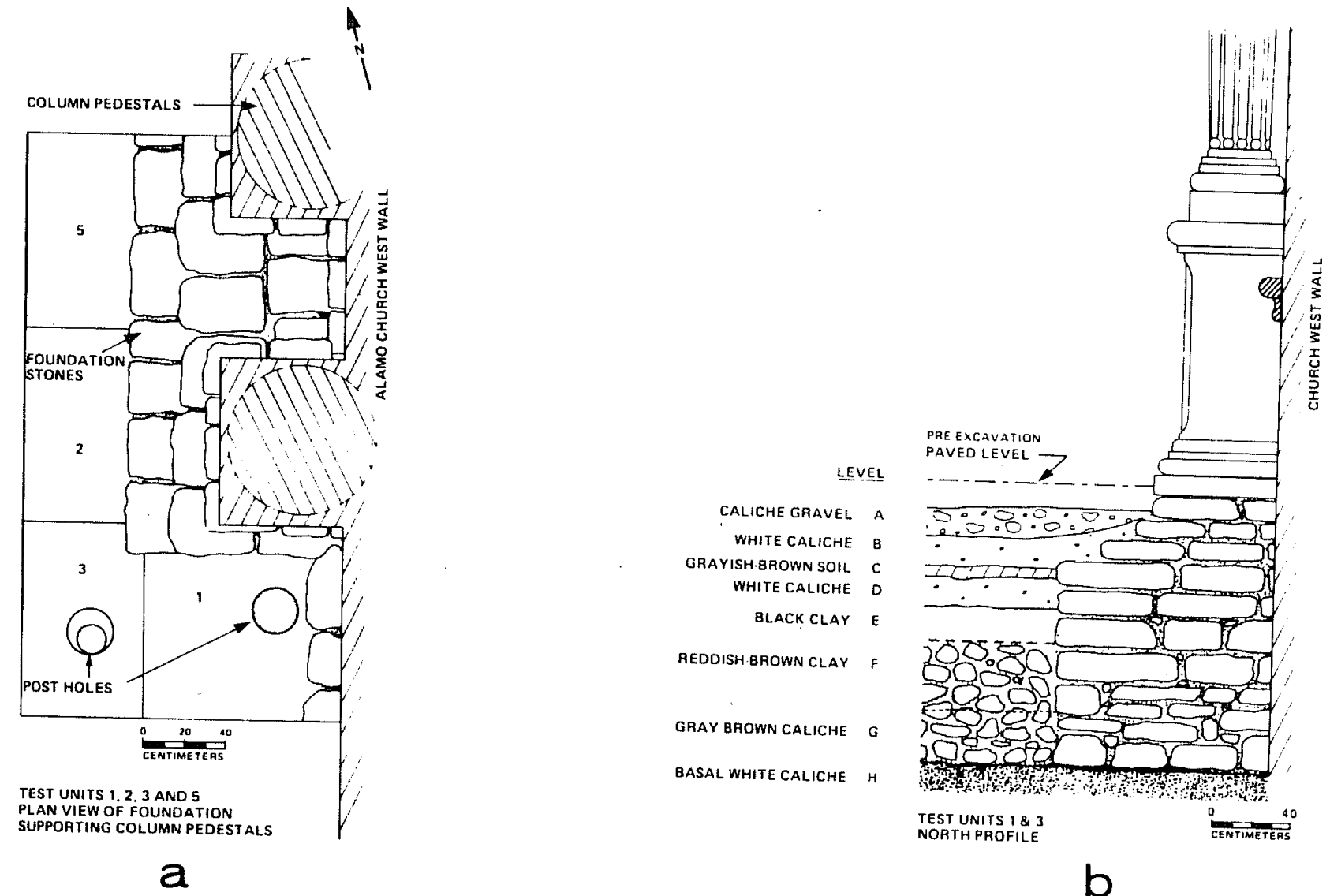

b

Figure 9. Alamo Shrine Excavations at the Front Column Pedestals. Shown are 


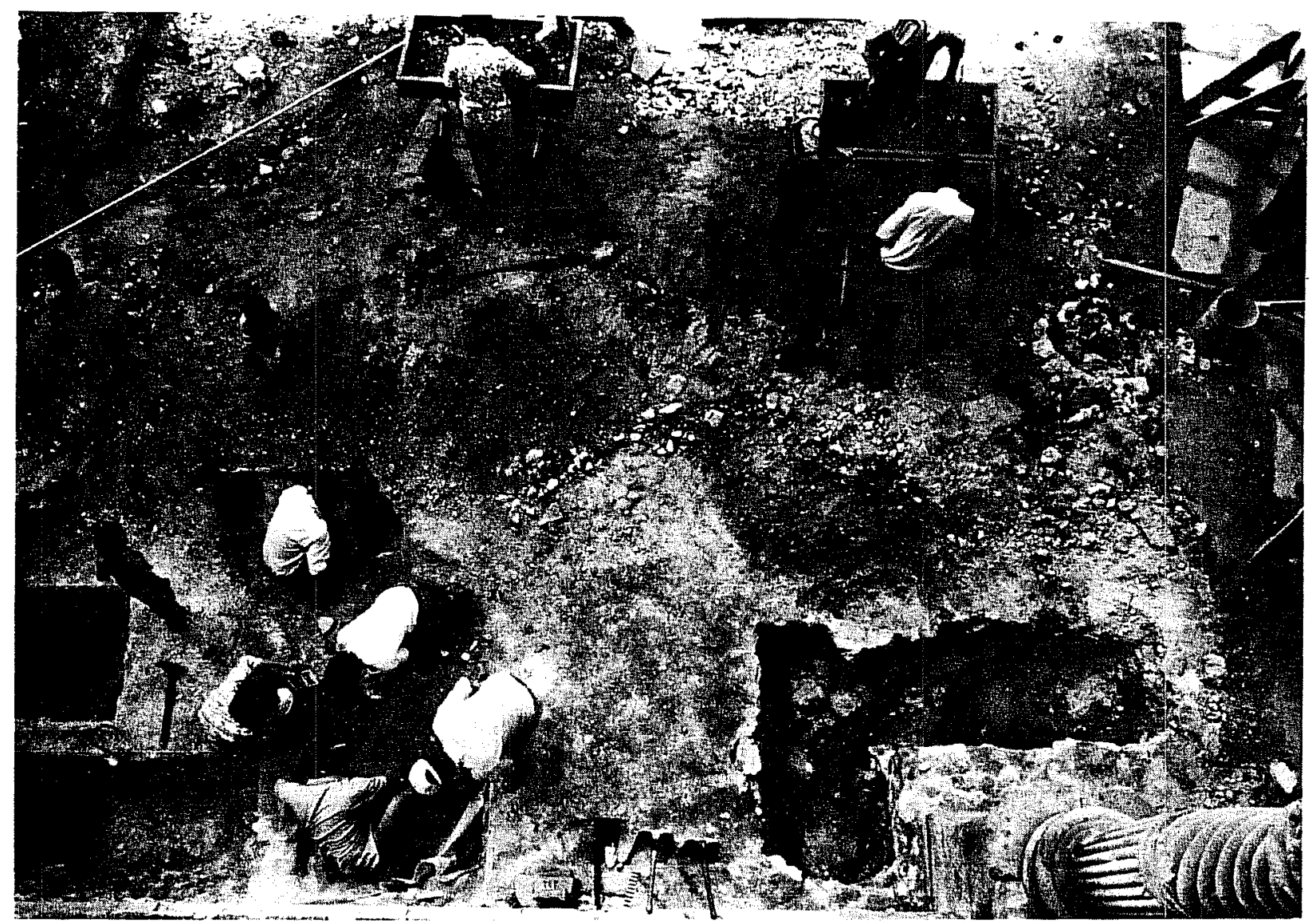

a

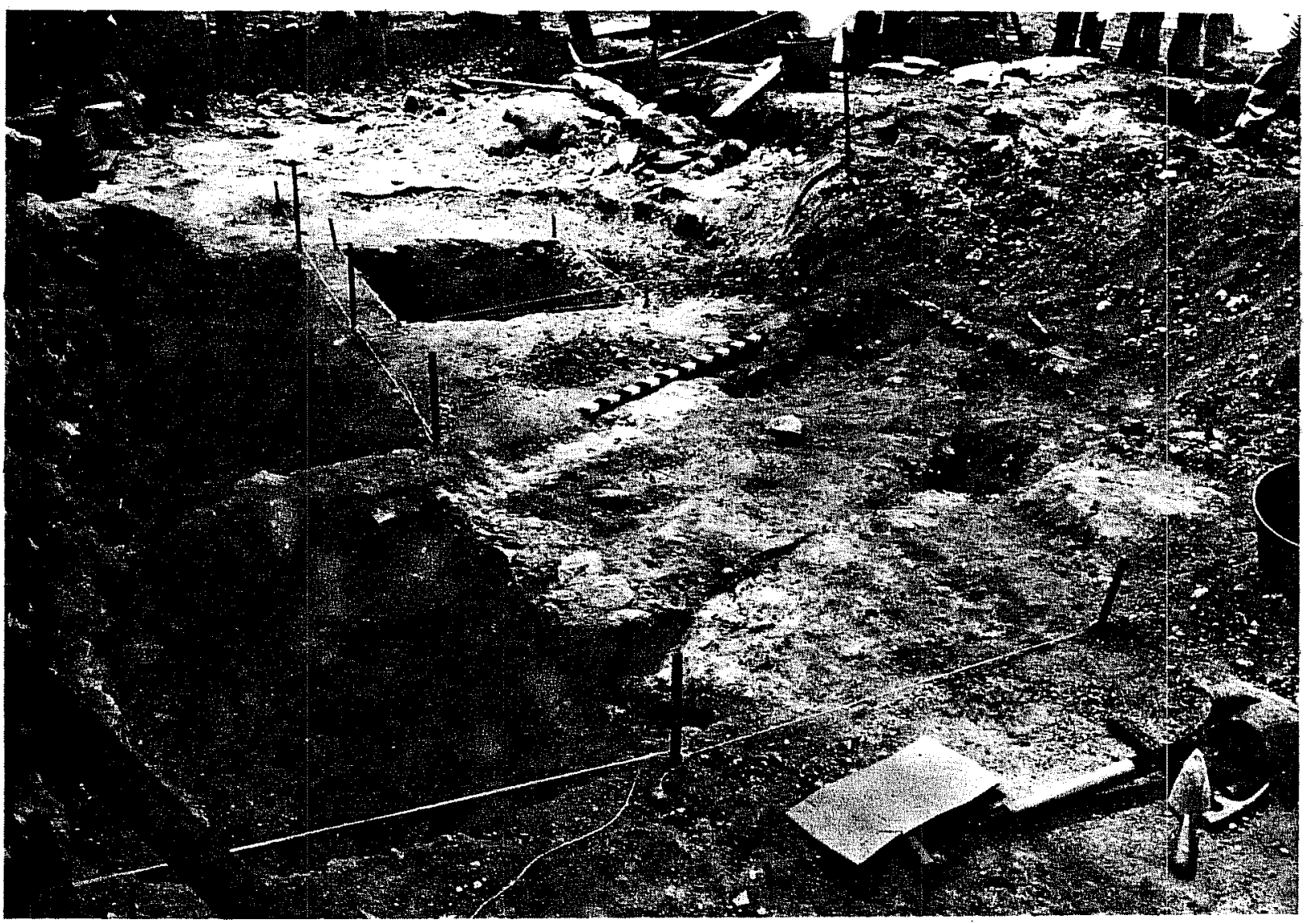

Figure 10. Alamo Shrine Excavations. a, view from Alamo roof showing location of excavations and palisade trench; $b$, palisade trench during excavation. 

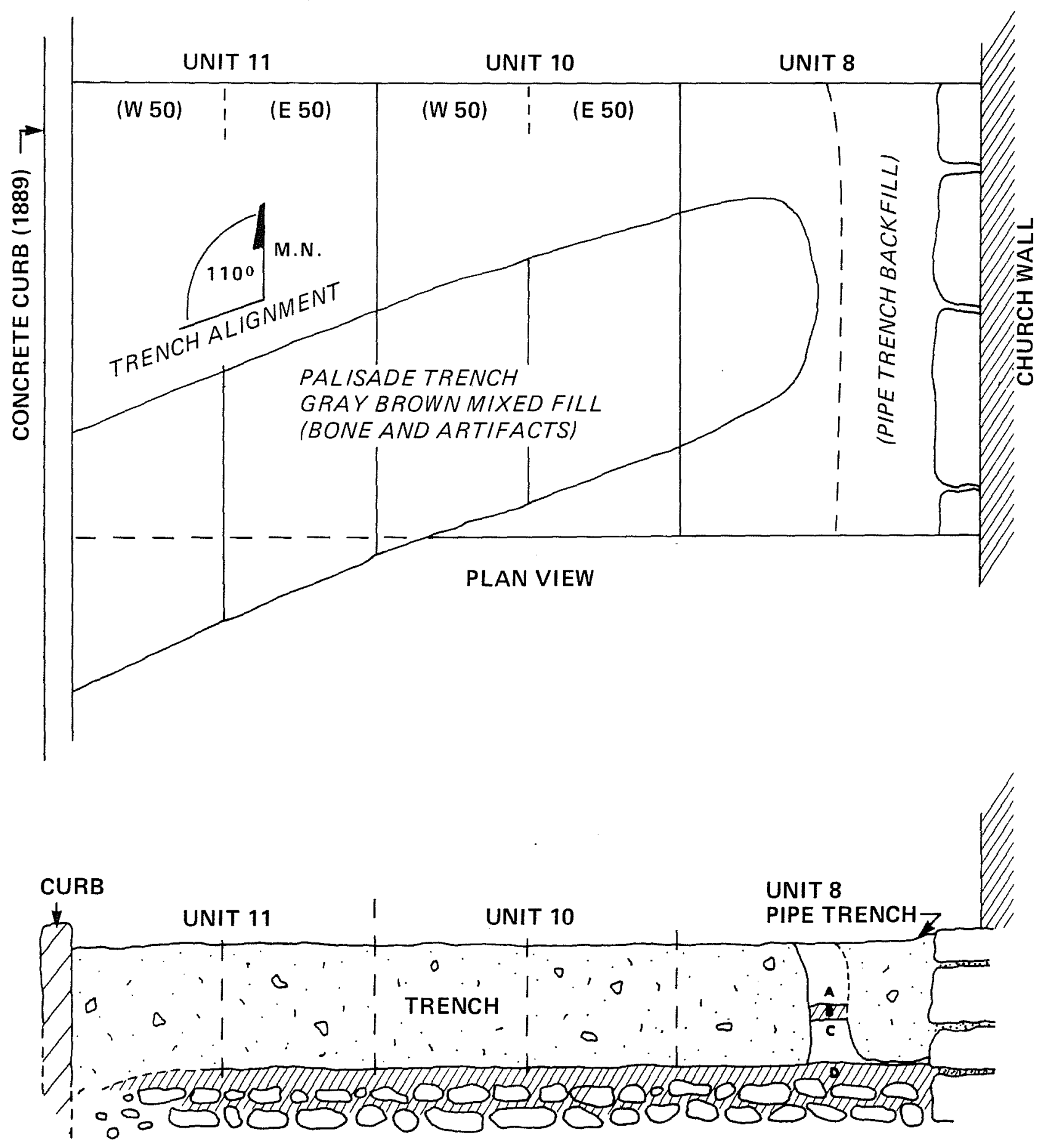

NORTH PROFILE

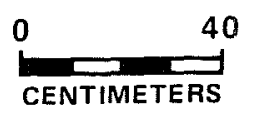

Figure 11. Palisade Trench. Located at southwest corner of Alamo Shrine. Shown are plan and profile views as determined by excavation. 


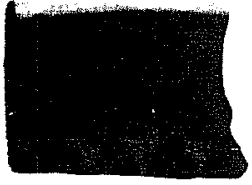

a

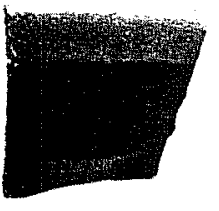

e
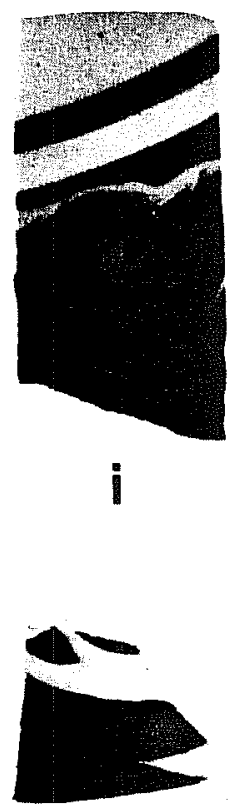

$m$

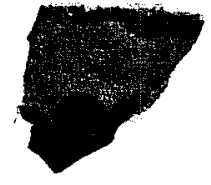

b

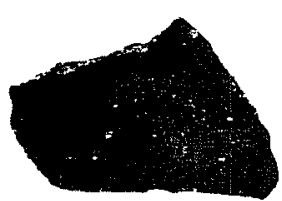

f

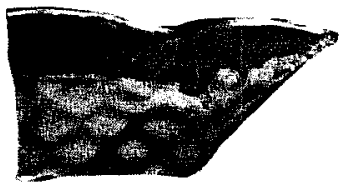

j

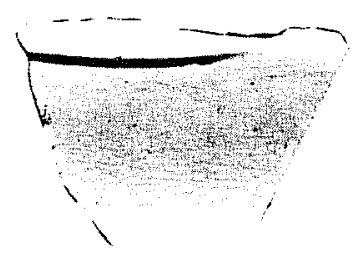

k
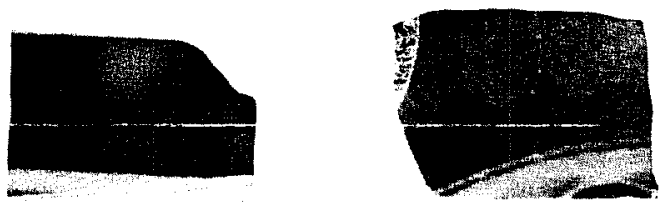

p

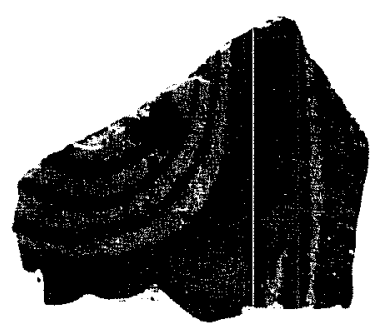

d

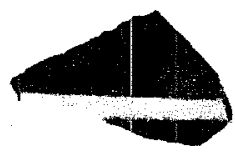

h

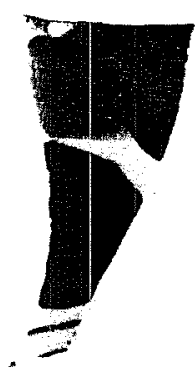

I

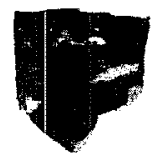

$q$

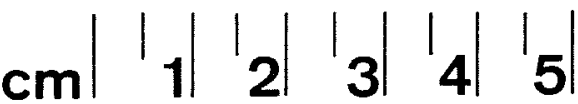

Figure 12. Ceramic Artifacts. a, Guanajuato Poluchrome majolica; b-c, Puebla Blue-on-White majolica; d, Puebla Polychrome majoijica; e, Aranama Polychrome majolica; f, Goliad ware; g-i, Mocha Polychrome; j, blue shell-edged pearlware; $k$, plain white pearlware; 1, hand-painted polychrome pearlware; m, hand-painted blue pearlware; $n$, hand-painted blue and green pearlware; 0 , brown-banded pearlware; $p-q$, blue transfer-printed pearlware. 


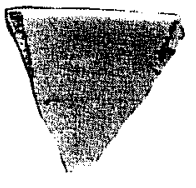

a

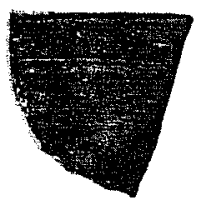

e

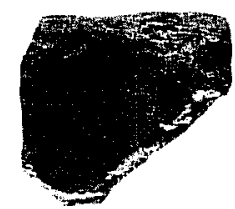

b

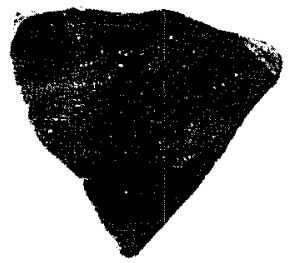

f

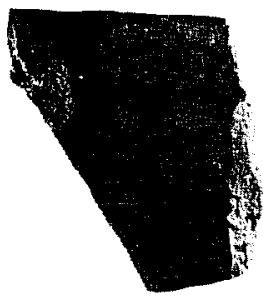

C

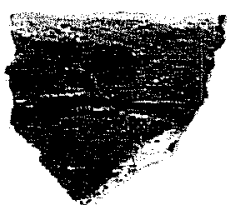

$\mathbf{g}$

h
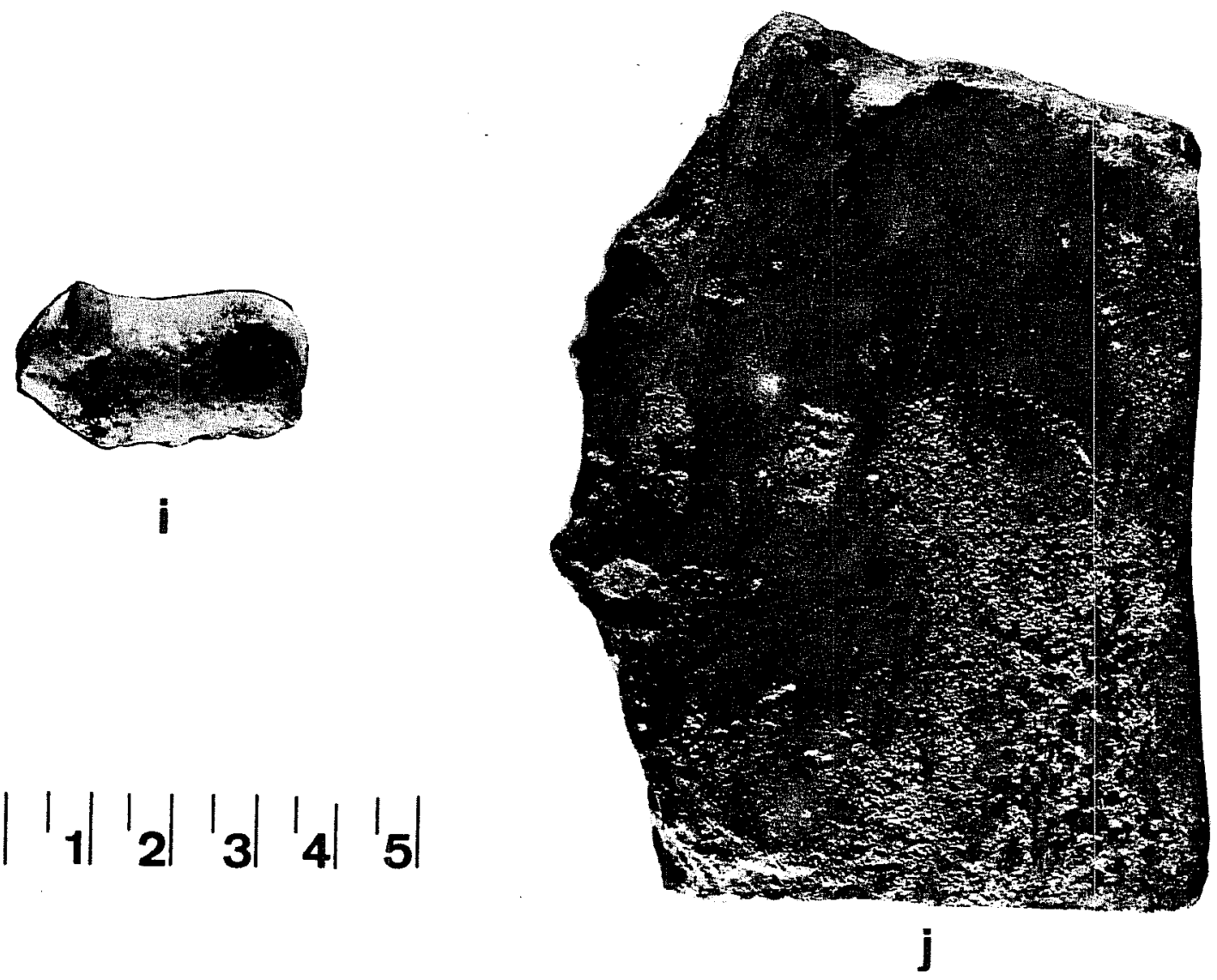

$\mathrm{cm}\left|{ }_{1}{ }_{1}\right| I_{2}\left|I_{3}\right| I_{4}\left|I_{5}\right|$

Figure 13. Ceramic Artifacts. a, creamware; b, sandy-paste glazeware; c, Tonalá ware; d, plain unslipped utility ware (buff paste); e, plain unslipped utility ware (pink paste); $f$, red-painted utility ware; $g$, redpainted and incised utility ware; $h$, oriental porcelain; $i$, glazed animal figure; $j$, pink ceramic tile. 

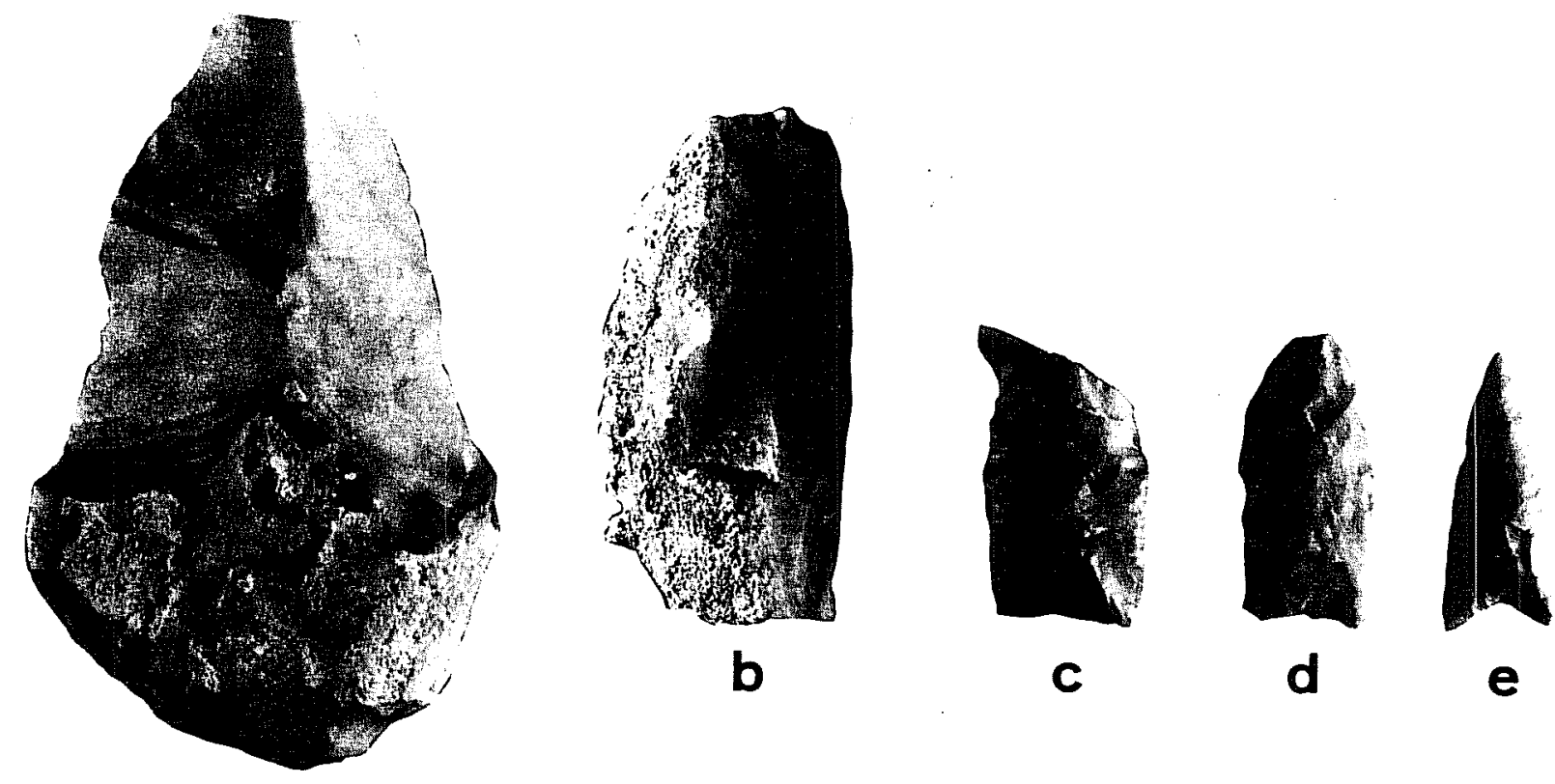

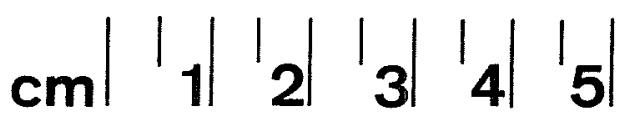
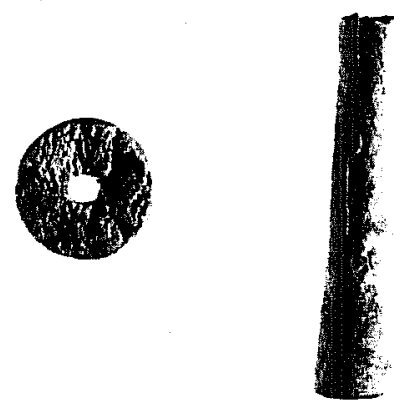

$\mathbf{f}$

$\mathbf{g}$

Figure 14. Chert and Bone Artifacts. $a$, chert end scraper; $b$, chert side scraper; c-e, chert "mission" points; $f$, bone button; $g$, bone tubular bead. 


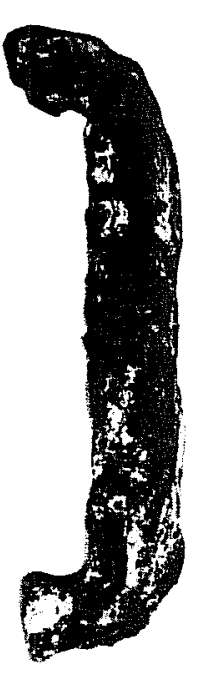

a

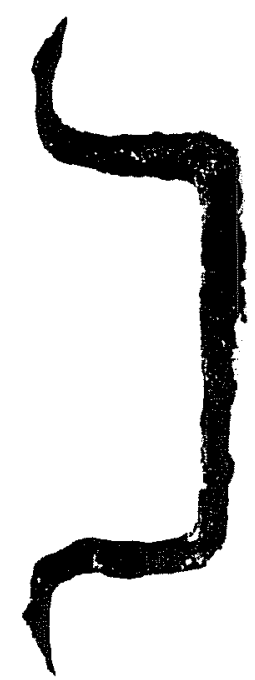

b
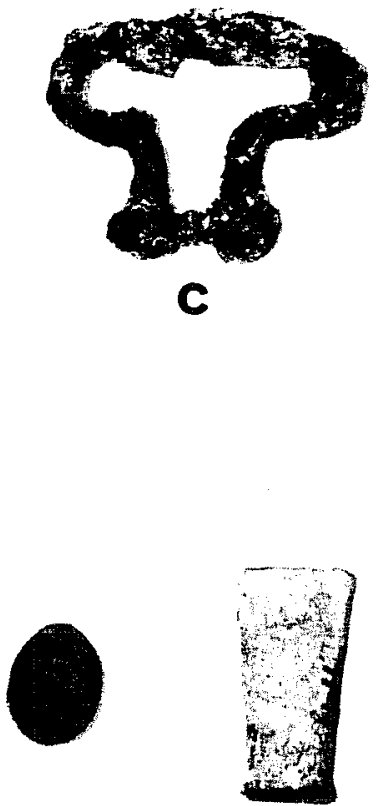

d
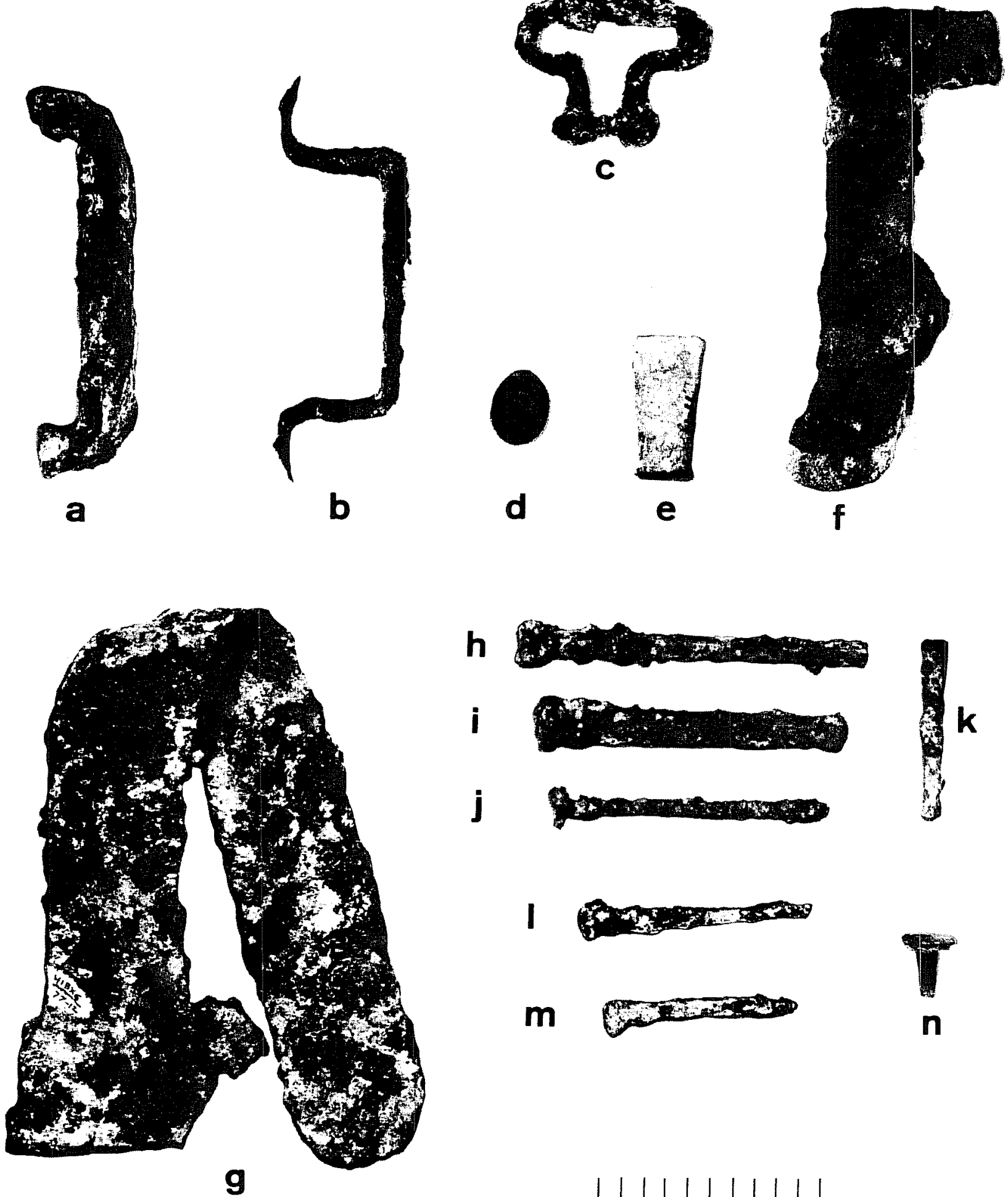

ก
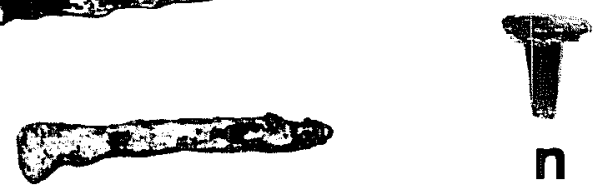

ก

Figure 15. Metal Artifacts. a, iron handle; b, iron bracket; $c$, sling swivel for musket; d, brass button; e, .44 or .45 caliber center-fire cartridge; $f$, iron tool; g, iron strap; $h-m$, square iron nails; $n$, square tack. 


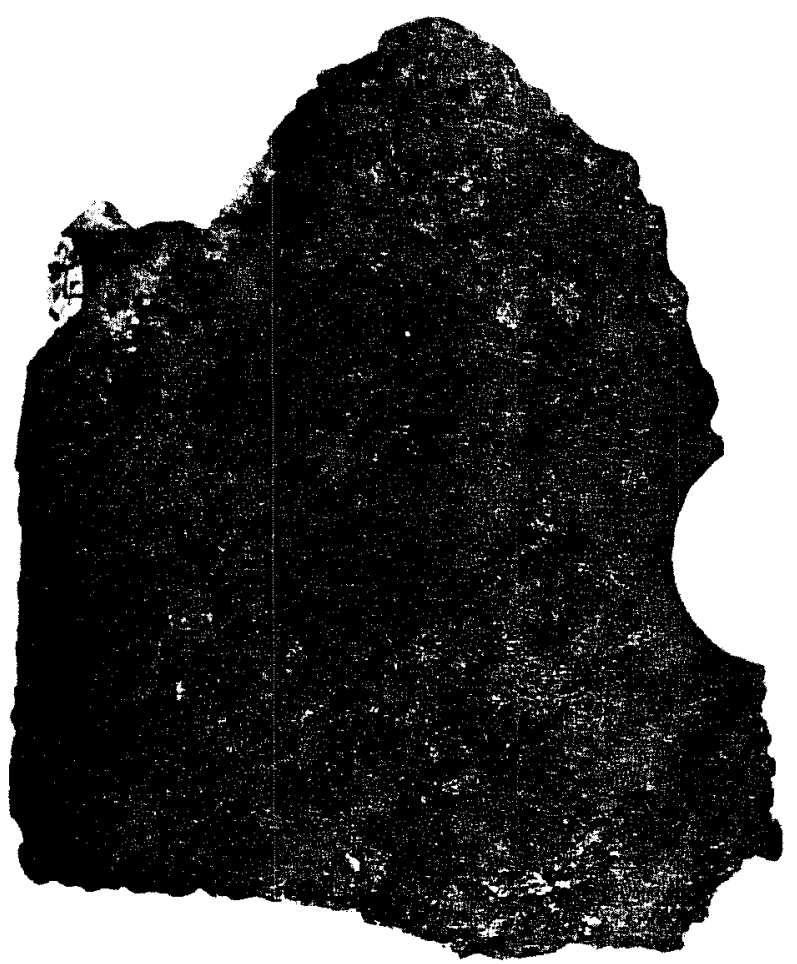

a

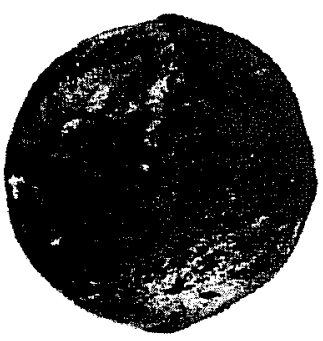

b

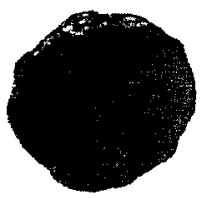

f

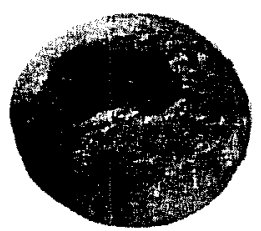

C

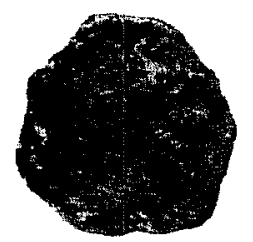

g

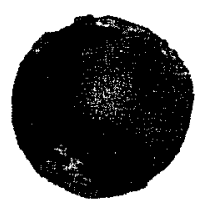

d

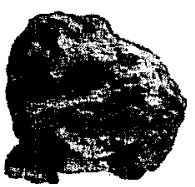

h

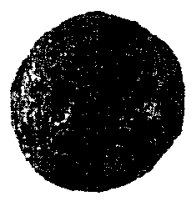

e

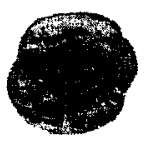

i

\begin{tabular}{llllll|l|l} 
& 1 & 1 & 1 & 1 & 1 \\
& & 2 & 3 & 4 & 5
\end{tabular}

Figure 16. Metal Artifacts. a-a', fragment of 8-in. bronze spherical shell with fuse hole; b, bronze spherical canister or grape shot; $c$, bronze spherical canister shot; d, .70 cal. lead musket bal1; e-f, .69 cal. lead musket bal1; $\mathrm{g}$-h, impacted lead musket ball; $i, .48 \mathrm{cal}$. musket or pistol lead ball. 


\section{REFERENCES CITED}

Adams, R. E. W., and Thomas R. Hester

1973 Letter to Dr. Fred Wendorf, Chairman, Texas Antiquities Committee, Concerning Completion of Excavations at Mission San Antonio de Valero, November 26.

Almaraz, Felix D., Jr.

1979 Crossroad of Empire: The Church and State on the Rio Grande Frontier of Coahuila and Texas, 1700-1821. Center for Archaeological Research. The University of Texas at San Antonio, Archaeology and History of the San Juan Bautista Mission Area, Coahuila and Texas, Report 1.

Baird, Joseph Armstrong, Jr.

1962 The Churches of Mexico, 1530-1810. University of California Press.

Bannon, John Francis, ed.

1964 Bolton and the Spanish Borderlands. University of OKlahoma Press, Norman.

Barker, Eugene C., ed.

1929 Texas History. Southwest Press, Dallas.

Bolton, Herbert E.

1907 Spanish Mission Records at San Antonio. Southwestern Historical Quarterly 10:297-307.

Campbe 11, T. N.

1962 Origins of Pottery Types from the Coastal Bend Region of Texas. Bulletin of the Texas Archeological Society 32 (for 1961):331-336.

1975 The Payaya Indians of Southern Texas. Southern Texas Archaeological Association, Special Publication 1.

1979 Ethnohistoric Notes on Indian Groups Associated with Three Spanish Missions at Guerrero, Coahuila. Center for Archaeological Research, The University of Texas at San Antonio, Archaeology and History of the San Juan Bautista Mission Area, Coahuila and Texas, Report 3.

Chabot, Fredrick $C$.

1931 Alamo: Altar of Texas Liberty. San Antonio. 
Chabot, Fredrick C. (continued)

1941 The Alamo: Mission Fortress and Shrine. San Antonio.

Corner, William

1890 San Antonio de Bexar: A Guide and History. Bainbridge and Corner, San Antonio.

Crawford, Michael $\mathrm{H}$.

1976 The Tlaxcaltecans: Prehistory, Demography, Morphology and Genetics. University of Kansas Publications in Anthropology 7. Lawrence, Kansas.

Eaton, J. D.

1975 Preliminary Report on Archaeological Investigations at Mission San Bernardo. In Archaeology and Ethnohistory of the Gateway Area, Middle Rio Grande of Texas. Report submitted to the National Endowment for the Humanities by the Center for Archaeological Research, The University of Texas at San Antonio.

1976 Archaeological Excavations at Missions San Juan Bautista and San Bernardo. In Archaeology and Ethnohistory of the Gateway Area, Middle Rio Grande of Texas. Report submitted to the National Endowment for the Humanities by the Center for Archaeological Research, The University of Texas at San Antonio.

1980 Guerrero, Coahuila, Mexico. A Guide to the Town and Missions (Guia de la Ciudad y de los Misiones). Center for Archaeological Research, The University of Texas at San Antonio, Archaeology and History of the San Juan Bautista Mission Area, Coahuila and Texas, Report 4.

Ford, Powe11, and Carson

1979 The Alamo Master Plan. Report prepared for the Daughters of the Republic of Texas. Ford, Powe11, and Carson, Architects and Planners, Inc., San Antonio.

Fox, Anne A.

1977 Archaeological Observations at Alamo Plaza. Unpublished report on file at the Center for Archaeological Research, The University of Texas at San Antonio.

Fox, Anne A., Feris A. Bass, Jr., and Thomas R. Hester

1976 The Archaeology and History of Alamo Plaza. Center for Archaeological Research. The University of Texas at San Antonio, Archaeological Survey Report 16. 
Fox, Daniel E.

1979 The Lithic Artifacts of Indians at the Spanish Colonial Missions, San Antonio, Texas. Center for Archaeological Research. The University of Texas at San Antonio, Special Report 8.

Garrett, Julia Kathryn

1939 Green Flag Over Texas. Cordova Press, New York.

Greer, John W.

1967 A Description of the Stratigraphy, Features and Artifacts from an Archeological Excavation at the Alamo. State Building Commission, Archeological Program, Report 3.

Habig, Marion A.

1977 The Alamo Mission: San Antonio de Valero 1718-1793. Franciscan Herald Press, Chicago.

Hester, T. R.

1977 The Lithic Technology of Mission Indians in Texas and Northeastern Mexico. Lithic Technology 6(1-2):9-13.

Hoyt, E.

1811 Practical Instructions for Military Officers. Greenwood Press, Westport, Conn.

Hughes, B. P.

1969 British Smooth-Bore Artillery: The Muzzle Loading Artillery of the 18th and 19th Centuries. Stackpole Books, PA.

Jones, Oakah L., ed.

1974 The Spanish Borderlands--A First Reader. Lorrin L. Morrison, Publisher.

Leutenegger, Benedict

1977 Inventory of the Mission San Antonio de Valero: 1722. Texas

Historical Commission, Office of the State Archeologist,

Special Report 23.

Manucy, Albert

1949 Artillery Through the Ages. National Park Service Interpretive Series, History 3. U.S. Government Printing Office, Washington, D.C. 
Markmann, Sidney David

1966 Colonial Architecture of Antigua, Guatemala. The American Philosophical Society, PA.

McAndrew, John

1969 The Open-Air Churches of Sixteenth-Century Mexico. Harvard University Press, Cambridge.

Nevin, David

1975 The Texans. Time-Life Books, New York.

Nixon, Pat Ireland

1936 A Century of Medicine in San Antonio: The Story of Medicine in Bexar County, Texas. Privately published by the author, San Antonio, Texas.

Perry, Carmen (trans. and ed.)

1975 With Santa Anna in Texas: A Personal Narrative of the Revolution. By Jośe Enrique de la Peña. Texas A\&M University Press, College Station.

Peterson, Harold $L$.

1969 Round Shot and Rammers. Bonanza Books, New York.

Price, W. Armstrong

1933 Reynosa Problem of South Texas, and Origin of Caliche. Bulletin of the American Association of Petroleum Geologists $17(5): 488-522$.

Schuetz, Mardith $K$.

1966 Historic Background of the Mission San Antonio de Valero. State Building Commission, Archeological Program, Report 1.

1973 Archeological Investigations at Mission San Antonio de Valero, The Second Patio. Unpublished manuscript, Office of State Archeologist.

Smith, Cornelius C., Jr.

1967 William Sanders Oury, History Maker of the Southwest. University of Arizona Press, Tucson. 
Sorrow, William M.

1972 Archeological Salvage Excavations at the Alamo (Mission San Antonio de Valero), 1970. Texas Archeological

Salvage Project, Research Report 4.

Taylor, F. B., R. B. Hailey, and D. L. Richmond

1966 Soil Survey of Bexar County. U.S. Department of Agriculture, Soil Conservation Service, Series 1962, No. 12. Washington, D.C.

Turner, Martha Anne

1972 William Barrett Travis: His Sword and his Pen. Texian Press, Waco.

Webb, Walter Prescott, ed.

1952 Handbook of Texas (Vol. II of 2 vols.). Texas State Historical Association, Austin.

Weddle, Robert S.

1968 San Juan Bautista, Gateway to Spanish Texas. University of Texas Press, Austin.

Weems, John Edward

1971 Dream of Empire. Simon and Schuster, New York.

Wheeler, J. B.

1898 The Elements of Field Fortifications for the use of the Cadets of the United States Military Academy at West Point, N.Y. D. Van Nostrand Company, N.Y.

Williams, Amelia

1933 A Critical Study of the Siege of the Alamo and the Personnel of its Defenders. Southwestern Historical Quarter2y 36:252-287; 37:1-44,79-115,157-184,237-312.

Yoakum, Henderson

1855 History of Texas. Redfield, New York. 